\title{
The Economics of Small Business Finance: The Roles of Private Equity and Debt Markets in the Financial Growth Cycle
}

\author{
Allen N. Berger \\ Board of Governors of the Federal Reserve System \\ Washington, DC 20551 U.S.A. \\ and \\ Wharton Financial Institutions Center \\ Philadelphia, PA 19104 U.S.A. \\ Gregory F. Udell \\ Stern School of Business, New York University \\ New York, NY 10012 U.S.A. \\ Forthcoming, \\ Journal of Banking and Finance \\ Volume 22, 1998
}

\begin{abstract}
We examine the economics of financing small business in private equity and debt markets. Firms are viewed through a financial growth cycle paradigm in which different capital structures are optimal at different points in the cycle. We show the sources of small business finance, and how capital structure varies with firm size and age. The interconnectedness of small firm finance is discussed along with the impact of the macroeconomic environment. We also analyze a number of research and policy issues, review the literature, and suggest topics for future research.
\end{abstract}

JEL classification codes: G21, G28, G34, E58, L89

Key words: Venture Capital, Small Business Lending, Bank, Mergers

The opinions expressed do not necessarily reflect those of the Board of Governors or its staff. The authors thank Zoltan Acs, Mitch Berlin, Emilia Bonaccorsi, Seth Bonime, Mark Carey, Dan Covitz, Maria Filson, Hesna Genay, Gibi George, Mark Gertler, Jere Glover, Diana Hancock, Anil Kashyap, Nellie Liang, Zachary Magaw, Nicole Meleney, Loretta Mester, Don Morgan, Patricia Miller-Edwards, Charles Ou, Linda Pitts, Loretta Poole, Phil Strahan, Larry White, and John Wolken for help with the article.

Please address correspondence to Allen N. Berger, Mail Stop 153, Federal Reserve Board, 20th and C Sts. NW, Washington, DC 20551, call 202-452-2903, fax 202-452-5295, or email aberger@frb.gov. 


\section{Introduction}

The role of the entrepreneurial enterprise as an engine of economic growth has garnered considerable public attention in the 1990s. Much of this focus stems from the belief that innovation -- particularly in the high tech, information, and bio-technology areas -- is vitally dependent on a flourishing entrepreneurial sector. The spectacular success stories of companies such as Microsoft, Genentech, and Federal Express embody the sense that new venture creation is the sine qua non of future productivity gains. Other recent phenomena have further focused public concern and awareness on small business, including the central role of entrepreneurship to the emergence of Eastern Europe, financial crises that have threatened credit availability to small business in Asia and elsewhere, and the growing use of the entrepreneurial alternative for those who have been displaced by corporate restructuring in the U.S.

Accompanying this heightened popular interest in the general area of small business has been an increased interest by policy makers, regulators, and academics in the nature and behavior of the financial markets that fund small businesses. At the core of this issue are questions about the type of financing growing companies need and receive at various stages of their growth, the nature of the private equity and debt contracts associated with this financing, and the connections and substitutability among these alternative sources of finance. Beyond this interest in the micro-foundations of small business finance is a growing interest in the macroeconomic implications of small business finance. For example, the impact of the U.S. "credit crunch" of the early 1990s and the effect of the consolidation of the banking industry on the availability of credit to small business have also been the subject of much research over the past several years. Similarly, the "credit channels" of monetary policy -- mechanisms through which monetary policy shocks may have disproportionately large effects on small business funding -- has generated considerable analysis and debate. Other key issues, such as the link between the initial public offering (IPO) market and venture capital flows, prudent man rules regarding institutional investing in venture capital, and the role of small firm finance in financial system architecture are just beginning to attract research attention.

The private markets that finance small businesses are particularly interesting because they are so different from the public markets that fund large businesses. The private equity and debt markets offer highly structured, complex contracts to small businesses that are often acutely informationally opaque. This is in contrast to the public stock and bond markets that fund relatively informationally transparent large 
businesses under contracts that are more often relatively generic.

Financial intermediaries play a critical role in the private markets as information producers who can assess small business quality and address information problems through the activities of screening, contracting, and monitoring. Intermediaries screen potential customers by conducting due diligence, including the collection of information about the business, the market in which it operates, any collateral that may be pledged, and the entrepreneur or start-up team. This may involve the use of information garnered from existing relationships of the intermediary with the business, the business owner, or other involved parties. The intermediary then uses this information about the initial quality of the small business to set contract terms at origination (price, fraction of ownership, collateral, restrictive covenants, maturity, etc.). A contract design and payoff structure is chosen on the basis of the financial characteristics of the firm and the entrepreneur as well as the firm's prospects and the associated information problems. High risk-high growth enterprises whose assets are mostly intangible more often obtain external equity, whereas relatively low risk-low growth firms whose assets are mostly tangible more often receive external debt for reasons explored below. Finally, in order to keep the firm from engaging in exploitive activities or strategies, the intermediary monitors the firm over the course of the relationship to ascess compliance and financial condition, and exerts control through such means as directly participating in managerial decision making by venture capitalists or renegotiating waivers on loan covenants by commercial banks.

This paper has several motivations. The first is to provide as complete a picture as possible of the nature of the private equity and debt markets in which small businesses are financed based on currently available research and data. The second is to draw connections between various strands of the theoretical and empirical literature that have in the past focused on specific aspects of small firm finance but often have not captured the complexity of small business finance and the alternative sources of funding available to these firms. The third goal is to suggest extensions to the research in key areas related to the markets, contracts, and institutions associated with small firm finance and to highlight the relatively new data sources available to address these issues.

We proceed in the next section with a discussion of the idiosyncratic nature of small business finance, the private markets that provide this finance, and an overview of key research issues. In Sections 
III and IV, we examine more closely the extant literatures on private equity markets and private debt markets, respectively. Section $\mathrm{V}$ discusses the vulnerability of small business finance to the macroeconomic environment. Section VI draws some tentative conclusions and suggests areas for future research.

\section{An Overview of Small Business Finance and Key Research Issues}

Perhaps the most important characteristic defining small business finance is informational opacity. Unlike large firms, small firms do not enter into contracts that are publicly visible or widely reported in the press -- contracts with their labor force, their suppliers, and their customers are generally kept private. In addition, small businesses do not issue traded securities that are continuously priced in public markets and (in the U.S.) are not registered with the Securities and Exchange Commission (SEC). Moreover, many of the smallest firms do not have audited financial statements at all that can be shared with any provider of outside finance. As a result, small firms often cannot credibly convey their quality. Moreover, small firms may have difficulty building reputations to signal high quality or nonexploitive behavior quickly to overcome informational opacity.

The private equity and debt markets we study here offer specialized mechanisms to address these difficulties. As noted above, the financial intermediaries that operate in these markets actively screen, contract with, and monitor the small businesses they invest in over the course of their relationships to help resolve these information problems. Indeed, it can be argued that the modern theory of financial intermediation -- which motivates intermediaries as delegated monitors on behalf of investors (e.g., Diamond 1984, Ramakrishnan and Thakor 1984, and Boyd and Prescott 1986) -- is mostly a theory that applies to the provision of intermediated finance in private markets to small, informationally opaque firms.

\section{Data on Small Business Finance}

The feature of small business finance that makes it the most interesting to study, informational opacity, also has made it one of the most difficult fields in which to conduct empirical research until recently. Small businesses are generally not publicly traded and therefore are not required to release financial information on $10 \mathrm{~K}$ forms, and their data are not collected on CRSP tapes or other data sets typically employed in corporate finance research. Some data are collected on lending by regulated financial institutions like commercial banks and thrifts, but these data traditionally were not broken down by the size 
of the borrower. Although a few surveys have been conducted on small businesses, these data were not widely circulated among researchers. The lack of detailed micro data on small businesses and the funds they raise in private equity and debt markets is likely a major reason why -- until very recently -- small business finance has been one of the most underresearched areas in finance.

However, this situation is changing rapidly, as several data sets have recently become available that make it much easier to describe the state of small business finance and to test the extant theories of financial intermediation and informational opacity. Data sets with information on U.S. small firms include the National Survey of Small Business Finances (NSSBF) and National Federation of Independent Business survey (NFIB), both of which canvas small businesses for their balance sheet and income data and their use of financial intermediaries, trade credit, and other sources of funds. These data allow for tests of research questions regarding the cost and availability of different types of external finance and how the cost and availability vary with the characteristics of the small firms. The Survey of Consumer Finances (SCF) collects detailed financial information from households, including their ownership of small businesses, and whether they also lend to these firms or provide support through the pledging of personal collateral or through loan guarantees. These data allow for tests of the roles of personal wealth and other personal characteristics in financing small businesses. The Survey of Terms of Bank Lending (STBL) provides detailed information since 1977 on the contract terms on some of the individual loans issued by a sample of banks, including the largest banks in the nation. Beginning in 1997, the STBL includes the banks' risk ratings on their individual loans, and data on loans issued by agencies and branches of foreign banks (Brady, English, and Nelson 1998). Bank call reports (CALL) since 1993 have provided data on the number and total dollar values of loans issued to businesses with small amounts of bank credit. Community Reinvestment Act (CRA) data that were first collected in 1997 help augment these data by giving more information on the size of the borrowers (annual revenues above versus below $\$ 1$ million), and their location by census tract (Bostic and Canner 1998). The STBL, CALL, and CRA data sources allow researchers to test the empirical connections between bank characteristics and the supply of small business credit. Detailed data on private equity markets are considerably sparser than data on private debt markets, but some progress is being made here as well. Venture Economics and VentureOne provide information on venture capital markets, data on both venture 
capital and angel finance may be gleaned from the NSSBF, some data on angel finance is obtainable from the SCF, and the Small Business Administration (SBA) provides some information on Small Business Investment Companies (SBICs). Details about these data sets, their uses in research, and how to gain access to them are provided in Wolken (NSSBF, SCF, STBL, CALL, CRA, others), Dunkelberg (NFIB), and Fenn and Liang (Venture Economics, VentureOne, others).

Data on small firms and their suppliers of external finance have also been generated recently in other countries and have been used in recent research efforts. These include data from Eastern Europe (Karsai, et al. 1997), Germany (Elsas and Krahnen 1997, Harhoff and Korting 1997), Italy (Angelini, Di Salvo, and Ferri 1998), Norway (Ongena and Smith 1997), Russia (Cook 1997), Trinidad/Tabago (Storey 1997), and the U.K. (Cressy and Toivanen 1997, Wright, Robbie and Ennew 1997). The problems of small business finance likely apply with even greater force to small businesses in developing nations, but very little data are available from these nations (White 1995).

\section{U.S. Small Business Finance at a Glance}

We next take a look at U.S. data. Table 1 shows the distribution of finance for U.S. small business finance across types of private equity and debt. The data in Table 1 are drawn primarily from the 1993 National Survey of Small Business Finance (NSSBF) and are book values weighted to represent all nonfarm, nonfinancial, nonreal-estate U.S. businesses as a whole, using the SBA classification of firms with fewer than 500 full-time equivalent employees. We caution that these data are not completely accurate or consistent, and should be considered rough estimates intended only to give a general idea of where small businesses receive their funding.

Table 1 shows that like large corporations, small businesses depend on both equity (49.63\%) and debt $(50.37 \%)$. We have broken down funding sources into four categories of equity and nine categories of debt. Panel A shows that the biggest equity category is funds provided by the "principal owner" at $31.33 \%$ of total equity plus debt or about two-thirds of total equity. The principal owner is typically the person who has the largest ownership share and has the primary authority to make financial decisions. The next biggest equity category is "other equity" at $12.86 \%$, which includes other members of the start-up team, family, and friends. "Angel finance" accounts for an estimated 3.59\%, but this is less precise than the other figures in 
our tables." "Angels" are high net worth individuals who provide direct funding to early-stage new businesses. Venture capital -- intermediated funds that are provided in a more formal market than angel finance -- provide $1.85 \%$ of small business finance. ${ }^{2}$ About $80 \%$ of venture capital is provided by independent limited partnership venture capital funds, with much of the remainder provided by subsidiaries of financial institutions, including bank holding companies.

The nine categories of debt are divided into three categories of funding provided by financial institutions (commercial banks providing $18.75 \%$ of total finance, finance companies $4.91 \%$, and other financial institutions $3.00 \%$ ), three categories provided by nonfinancial and government sources (trade credit $15.78 \%$, other business $1.74 \%$, and government $0.49 \%$ ), and three categories provided by individuals (principal owner $4.10 \%$, credit cards $0.14 \%,{ }^{3}$ and other individuals $1.47 \%$ ).

These statistics reveal that the largest sources of finance for small businesses are the principal owner (including owner's equity, loans, and credit card debt), commercial banks, and trade creditors, which together account for $70.10 \%$ of total funding. Panels B and C of Table 1 break out the data by size and age of the small business, respectively, and this same general result holds throughout -- these three sources are the largest three for every size and age group, and in all cases provide more than half of total funds. Nonetheless,

'Angel finance estimates range from $\$ 15$ billion to $\$ 120$ billion. The lower bound is estimated based on NSSBF information on the number of small business corporations that raise equity from outside investors and from existing shareholders that are likely to be angel investors. Annual investments originated are estimated to average between $\$ 250,000$ and $\$ 400,000$ each for about 10,000 companies, or about $\$ 2.5$ billion to $\$ 4.0$ billion total invested. Assuming an average investment period of six years, these origination data suggest a steady state of between $\$ 15$ billion and $\$ 24$ billion outstanding. The upper bound is based on data from surveys of private investors and those with net worth of more than $\$ 1$ million summarized in Freear, Sohl, and Wetzel (1994). They suggest that angels provide between $\$ 10$ billion and $\$ 20$ billion of total new investments to about 30,000 companies each year. Based on an average investment period of six years, these data would imply between $\$ 60$ billion and $\$ 120$ billion in angel finance outstanding. We choose the lower bound of the information drawn from the survey data on investors because the NSSBF does not directly ask about angel finance, and emphasize the caveat that this is a very imprecise estimate.

${ }^{2}$ The use of the term "venture capital" is not uniform. Sometimes it refers to any equity investment in a new or early stage venture, including angel finance. However, we wish to distinguish between the informal angel finance market and the formal intermediated venture capital market to which we refer here.

${ }^{3}$ Credit card debt includes both the firm's credit card debt and the owner's credit card debt when used for firm purchases because these two are not separable in the data. We place the total under the principal owner here in order not to understate the owner's contribution to funding the firm, although the total is so small that it is unlikely to create much error either way. 
there are some interesting differences. As might be expected, "larger" small businesses (more than 20 employees or more than $\$ 1$ million in sales) have lower shares of funding provided by the principal owner through equity, principal owner loans, or credit cards; receive more funding from commercial banks and finance companies; and are more highly levered overall than "smaller" small businesses. Space constraints prevent extended discussion here, but we will discuss some surprising results by firm age in our discussion next about the financial growth cycle of small business. ${ }^{4}$

\section{The Financial Growth Cycle of Small Business}

Small business may be thought of as having a financial growth cycle in which financial needs and options change as the business grows, gains further experience, and becomes less informationally opaque. Figure 1 shows this in a stylized fashion in which firms lie on a size/age/information continuum. Smaller/younger/more opaque firms lie near the left end of the continuum indicating that they must rely on initial insider finance, trade credit, and/or angel finance. ${ }^{5}$ We define initial insider finance as funds provided by the start-up team, family, and friends prior to and at the time of the firm's inception. As firms grow, they gain access to intermediated finance on the equity side (venture capital) and on the debt side (banks, finance companies, etc.). Eventually, if the firms remain in existence and continue to grow, they may gain access to public equity and debt markets. We emphasize that the growth cycle paradigm is not intended to fit all small businesses, and that firm size, age, and information availability are far from perfectly correlated. We also emphasize that Figure 1 is intended to give a general idea of which sources of finance become important at different points in the financial growth cycle, and the points in the cycle at which different types of funding are shown to begin and end are not intended to be definitive. For example, even the very largest firms occasionally obtain funding through bank loans or private placements, but this is not shown in the figure.

\footnotetext{
${ }^{4}$ One source of finance not shown in Table 1 -- which is neither conventional equity nor conventional debt -- is finance from certain types of strategic alliances. In some cases, a large firm provides funding for R\&D or other activity to a small firm in exchange for future considerations, such as the right to market the small firm's product when it is ready for market. This occurs in many small biotechnology companies, which have high growth potential, but require large amounts of capital for $R \& D$ several years before their products are likely to come to market (Majewski 1997).
}

${ }^{5}$ Figure 1 is adapted and updated from Carey et al. (1993, Figure 10). 
The notion that firms evolve through a financial growth cycle is well established in the literature as a descriptive concept. ${ }^{6}$ The perceived wisdom that start-up financing is heavily dependent on initial insider finance, trade credit, and angel finance (Sahlman 1990, Wetzel 1994) is appealing theoretically because startup firms are arguably the most informationally opaque and, therefore, have the most difficulty in obtaining intermediated external finance. Initial insider finance is often required at the very earliest stage of a firm's development when the entrepreneur is still developing the product or business concept and when the firm's assets are mostly intangibles. Insider finance may be required again when the business begins small scale production with a limited marketing effort. ${ }^{7}$ This "start-up stage" is often associated with the development of a formal business plan which is used as a sales document to obtain angel finance. Venture capital would typically come later, after the product has been successfully test-marketed, to finance full-scale marketing and production. Sometimes, however, venture capital may be used to finance product development costs when those costs are substantial, such as financing clinical trials in the biotechnology industry. Venture capitalists often invest in companies that have already received one or more rounds of angel finance.

Conventional wisdom argues that bank or commercial finance company lending would typically not be available to small businesses until they achieve a level of production where their balance sheets reflect substantial tangible business assets that might be pledged as collateral, such as accounts receivable, inventory, and equipment. ${ }^{8}$ This sequencing of funding over the growth cycle of a firm can be viewed in the context of the modern information-based theory of security design and the notion of a financial pecking order. Costly state verification (Townsend 1979, Diamond 1984) and adverse selection (Myers 1984, Myers and Majluf 1984, Nachman and Noe 1994) arguments suggest the optimality of debt contracts after insider

\footnotetext{
${ }^{6}$ For example, there are generally accepted definitions of the stages of finance for the kind of high-growth companies that are attractive to angels and venture capitalists (Pratt and Morris 1987).

${ }^{7}$ Insider finance depends obviously on the financial resources of the entrepreneur. Thus, changes in demographics and wealth distribution may effect new firm formation (H.S. Rosen 1998). Rosen argued that the significant transfer of wealth that will occur when the heirs of the baby boom generation inherit their wealth beginning 25 years from now may spark a significant surge in new firm formation.
}

${ }^{8}$ See Brewer and Genay (1994) and Brewer et al. (1997) for empirical evidence that external private equity in the form of venture capital is more likely to be used to finance intangible assets and activities that generate little collateral while external private debt is more likely to be used to finance tangible assets. 
finance has been exhausted. These debt contracts could include trade credit, commercial bank loans and finance company loans. However, moral hazard can make debt contracts quite problematic. Moral hazard problems are likely to occur when the amount of external finance needed is large relative to the amount of insider finance (inclusive of any personal wealth at risk via pledges of personal collateral or guarantees). This suggests that external equity finance, specifically angel and venture capital, may be particularly important when these conditions hold and the moral hazard problem is acute. The fact that high-growth, high-risk new ventures often obtain angel finance and/or venture capital before they obtain significant amounts of external debt finance suggests that the moral hazard problem may be particularly acute for these firms. ${ }^{9}$

Until recently, data constraints have made it difficult to examine this paradigm empirically. A recent empirical analysis of the financial growth cycle (Fluck, Holtz-Eakin, and Rosen 1997) found results somewhat at variance with the perceived wisdom. Using data on Wisconsin businesses, they estimated that external finance exceeds insider finance at start-up. They also found that external finance declines as a proportion of total finance over the first 7-8 years of a business' life cycle, then increases thereafter. Because their data do not include trade credit, their results may understate the dependence on external finance throughout the life cycle. Their results suggest that perhaps informational opacity does not make it quite so difficult for young firms to obtain external finance, particularly debt from financial institutions, as is implied by the perceived wisdom about the financial growth cycle.

Panel $\mathrm{C}$ of Table 1 sheds further light on these and related issues about the evolution of small business finance over the growth cycle by showing the distribution of finance by firm age for our weighted national sample from the NSSBF. We categorize small businesses as "infants" (0-2 years), "adolescents" (3-4 years), "middle-aged" (5-24 years), or "old" (25 years or more), which may be viewed as a rough

\footnotetext{
${ }^{9}$ This is not the only argument that has been suggested as driving the optimality of the type of equity contracts we observe in venture capital, as we will discuss at greater length in Section III. Garmaise (1997) argued that the normal pecking order in which external debt precedes external equity can be reversed if it is assumed that venture capitalists have superior information to entrepreneurs. While it seems plausible to argue that entrepreneurs have a superior informational advantage over certain aspects of their project such as the feasibility of their projects' technology, it may be reasonable to assume that venture capitalists have superior information over a project's marketability and its operational implementation.
} 
approximation of seed, start-up, and later stages of finance discussed earlier.

One interesting phenomenon is that funds provided by the principal owner (equity plus debt) increase substantially as firms move into the middle age and old categories, from about $25 \%$ of funding to about $40 \%$. One reason may be the accumulation of retained earnings over time by principal owners of small businesses that are successful enough to survive into middle age or that the firms that succeed tend to start out with greater principal owner stakes. The principal owner may also use some of the retained earnings to obtain a larger equity share by buying out some of the other insider owners and insider debt. As noted above, much of the seed money often comes in the form of equity and debt from family and friends, and some of this may be repurchased by the firm as it grows and becomes more self-sufficient. As shown, the principal owner's equity increases over time by more than the total equity, consistent with the possibility that shares are being bought from other shareholders. In addition, debt held by the principal owner through loans and credit debt as well as debt held by other individuals (mostly family and friends) decline as the firm matures and retires these insider loans that were needed in the early stages.

These data also speak to the issue of insider finance versus outsider finance and how they vary over the financial growth cycle. Like the Wisconsin data, these weighted national data also appear to indicate that insider finance does not dominate external finance, even in the youngest firms. While data on angel and venture finance (as well as funding provided by other members of the start-up team) are not broken out for adolescents, we can calculate an upper bound to insider finance. For adolescents (Panel C) the principal owner provides $25.7 \%$. The majority of the remaining equity $(28.3 \%)$ is probably from other members of the start-up team. Likewise most of the debt from other individuals $(2.8 \%)$ is likely from insiders. This translates into an upper bound to insider finance of $56.8 \%$. Of this $56.8 \%$ some of the equity probably comes from angels (possibly more than the $3.6 \%$ for the whole population in Panel A) and some (but probably not much) comes from non-angel non-insiders. Venture capital is likely less important to adolescents than in the whole population (1.9\% in Panel A) because venture capitalists tend to avoid pure start-ups. Taken together, these data suggest that insider finance is roughly equal in importance to external finance for adolescents.

It is perhaps surprising how much funding is provided to young firms by external debt from financial 
institutions. This might be considered a violation of the conventional wisdom, which holds that external finance from these institutions may have to wait until the firm has shown some success and generated some business assets that could be pledged as collateral. However, this funding is not entirely external in an economic sense. As shown below, most small business loans provided by these institutions are personally guaranteed by the one or more of the inside owners, giving the financial institution recourse against their personal wealth in the event the loan is not repaid. In many cases, the personal assets of the insiders are also explicitly pledged as collateral to back the loans. In addition, the owners of small businesses that are organized as proprietorships and partnerships generally are not protected by the limited liability laws that govern corporations (except for limited partners), and so may have their personal wealth at stake to repay loans from financial institutions whether or not there is a formal guarantee or pledge of personal collateral. Thus, much of the "external" finance from financial institutions is at least partially "insider" finance in the sense that the insiders are legally required to assume much of the losses if the loans are not repaid.

This use of personal assets to help with external finance also highlights another important aspect of small business finance -- the financial intertwining of owners and their businesses (Ang 1992). Outside investors and intermediaries often put considerable weight on the financial conditions and reputations of the inside owners, and their own relationships with the inside owners when making investment decisions. For relatively new small businesses, it may often be easier and more informative to evaluate the creditworthiness of the entrepreneur, who may have a longer credit history, more pledgeable assets, and personal data that are relatively easy to evaluate using modern credit scoring techniques. This intertwining of personal and business finances often makes research on small business finance difficult, as data on the owners' finances are often unavailable to researchers.

We caution that the weighted averages in Table 1 mask considerable heterogeneity among types of firms and the funding they receive. We also caution that these data are from 1993 and therefore may not accurately reflect current conditions in small business finance. Firms with different types of earnings profiles are likely to be financed with different combinations of equity and debt. Small businesses in high-growth, high-risk sectors more often obtain external equity investments from angels and venture capitalists, whereas firms with steadier income flows more often obtain external debt finance from banks and other financial 
institutions. ${ }^{10}$ Similarly, small businesses with more generic physical inputs like motor vehicles, buildings, and simple equipment may more often borrow from financial institutions because they can use these inputs as collateral to back the loans.

It has been estimated that about $23.7 \%$ of small businesses disappear within 2 years and $52.7 \%$ disappear within 4 years due to failure, bankruptcy, owner retirement, owner health, or the desire to enter a more profitable endeavor (U.S. Small Business Administration 1995, Table A.14, p. 243). Thus, the firms that survive to be middle aged and old in Panel $\mathrm{C}$ are much better performers than the median small business, which likely is out of business before reaching these stages in the financial growth cycle.

Importantly, not all firms are structured financially in anticipation of following a path from inception to IPO. Some small businesses are simply "mom and pop" type enterprises, and are not managed to pursue a high growth strategy. Some are "life-style ventures" in which other arguments are prominent in the entrepreneur's objective function, such as being one's own boss (Wetzel 1994). This does not preclude profitability, but it may preclude the type of high-growth prospects that are so attractive to venture capitalists.

\section{The Interconnectedness of Small Firm Finance}

The financial growth cycle paradigm is also useful for highlighting the interconnectedness of the sources of small business finance enumerated in Table 1 as firms grow from the start-up stage, to "early stage" finance, to "later stage" finance, and ultimately public finance. Different sources of funding may be substitutes or complements. For example, the angel contract is often constructed in anticipation of possible future venture capital, indicating that angel finance and venture capital are often complementary sources. Likewise, the venture capital contract is written in anticipation of going public, suggesting that venture capital and public equity are also complements. Loans from commercial banks and other financial institutions are often predicated on having sufficient equity that was built up in the past through initial inside finance, angel finance, and venture capital (complementary). Other connections between types of finance are more subtle. A few examples found in the research that are discussed later in this article are illustrative:

${ }^{10}$ Consistent with this, Fenn, Liang, and Prowse (1997) found that venture capital-backed firms going public were much more likely to be in the computer-related and medical-related industries than other firms going public. 
- Dependence on trade credit is negatively related to the strength of the firm's relationship with its bank (substitutes);

- The announcement of a loan commitment may raise stock prices and reduce the cost of equity finance (complements).

- Bank borrowers who do not pledge collateral may send a favorable signal about quality that lowers the cost of other types of finance (complements);

Research on small business finance should take into account the connections among types of small business finance, including the expected effects of one type of finance on the future cost and availability of other types.

\section{Differences Between Small Business Finance and Large Business Finance}

Finally, there are some notable qualitative differences between the financing of small businesses on the left side of the size/age/information continuum in Figure 1 and the large businesses on the right side. The first, which has already been noted and is a major theme of this article, is that small businesses generally only have access to private equity and debt markets, whereas large businesses have access to public markets. We argue that informational opacity is a major reason why small firms cannot issue publicly traded securities, but it is not the only reason. Public equity and debt underwriting is characterized by significant costs associated with public market due diligence, distribution, and securities registration. Many of these costs are essentially fixed and create economies of scale in issue size. Given that issue size and asset size of the firm are strongly positively related, these economies of scale in issue size may be difficult for small and midsized businesses to overcome. Thus, a combination of informational opacity and issue costs will determine the size of firm for which a public offering becomes economically attractive. On the equity side, the median firm asset size was $\$ 16.0$ million for venture-backed IPOs, and $\$ 23.3$ million for nonventure-backed IPOs over 1991-93 (Fenn, Liang, and Prowse 1997). A reasonable guess for the minimum asset size for entering this market would be about $\$ 10$ million. For public debt side, a reasonable guess for the minimum firm asset size is about $\$ 150-\$ 200$ million. ${ }^{11}$

While we characterize small firms as obtaining external finance almost exclusively through private

${ }^{11}$ Carey et al. (1993) estimated that the issue size of public debt begins about $\$ 75-\$ 100$ million. Assuming that a firm's assets are at least twice as large as its public debt yields a minimum asset size for firms to issue in the public debt market of at least $\$ 150$ - $\$ 200$ million. 
equity and debt markets and not public markets, the converse does not generally hold for large firms. Even after firms are able to access public equity and debt markets, they often continue to use private markets, at least for certain types of transactions. Large firm LBOs typically involve raising substantial sums in the organized private equity markets (Fenn, Liang, and Prowse 1997). Similarly, firms with access to public debt markets often continue to use private debt markets heavily, with bank loans, private placements, and other private debt arrangements accounting for half or more of large corporate debt. Arguably, even large firms may engage in informationally opaque activities that required the information production services of a financial intermediary that can structure a tailored contract and monitor performance over the life of the contract (Carey et al. 1993, Houston and James 1996, Hadlock and James 1997).

Another difference between small and large firms is that most small firms are owner-managed. In the 1993 NSSBF, $86.0 \%$ of the firms are managed by an owner/partner, and only $14.0 \%$ by a hired employee/paid manager. As a result, agency problems in corporate governance and in choosing capital structure (e.g., free cash flow problems) that are driven by the separation of ownership and control are often irrelevant for small firms. ${ }^{12}$ The juxtaposition of ownership and management, however, may create its own set of problems. On the one hand, for example, an undiversified owner may pursue nonvalue-maximization behavior to reduce risk. On the other hand, the agency cost of debt might be higher without an intervening layer of risk averse management that would otherwise reduce risk.

\section{The Role of Private Equity Markets in Small Business Finance}

As noted earlier, all of the funds provided by the "principal owner" and most of the"other equity" in Table 1 represent insider finance. These funds are critical at the "seed financing" and "start-up" stages when information problems are most acute. Insider funding is also usually a necessary condition for any infusions of external finance to reduce adverse selection and moral hazard problems. At later stages of growth -- as represented by our "middle-aged" and "old" categories in Panel C of Table 1 -- retained earnings are often an important source of additional funding and serve as a source of strength to assure flows of external finance.

\footnotetext{
${ }^{12}$ An interesting exception occurs when a venture capitalist obtains a controlling interest in a firm still managed by the entrepreneur.
} 
Angel finance and venture capital -- at $3.59 \%$ and $1.85 \%$ of total finance, respectively -- represent relatively small portions of small business finance. However, this considerably understates the role of the external private equity market that is made up of these two categories for certain types of firms. Angels and venture capitalists invest very selectively and target small companies with significant upside potential. ${ }^{13}$ Thus, most of the infants and adolescents would not be candidates for angel finance, and the overwhelming majority would not be candidates for venture capital.

The importance of the external private equity can best be judged not by the quantity of this equity, but by the eventual success of the firms that receive it. In terms of the financial growth cycle paradigm, the big winners are usually those that are taken public in an IPO. ${ }^{14}$ During the $1980 \mathrm{~s}$, approximately $15 \%$ of all IPOs were backed by venture capital, well out of proportion to the fraction of all firms that received venture capital. Since 1990, this share has about doubled to 30\% (Fenn, Liang, and Prowse 1997). Moreover, discussions with industry participants indicate that most companies that receive venture capital had prior angel finance. We next turn to the structure of the angel and venture capital markets respectively.

\section{The Angel Finance Market}

Angel finance differs markedly from most other categories of external finance in that the angel market is not intermediated. Instead, it is an informal market for direct finance where individuals invest directly in the small companies through an equity contract, typically common stock. The modern theory of financial intermediation suggests that financial intermediaries exist in part because of economies of scale in information production. That is, they eliminate redundancy in information production when numerous small investors pool their funds into an intermediary and eliminate the delegation costs associated with financial intermediation. Because angels by definition and by SEC regulation are high net worth individuals,

\footnotetext{
${ }^{13}$ This type of finance is sometimes discussed in terms of a "target rate of return," or the rate that the angel or venture capitalist would realize in the most likely successful state. When they invest in early-stage firms, the target rate can be as high as $40-80 \%$ depending on the stage of finance with angels generally at the lower end and venture capitalists at the higher end. These target rates often require giving external equity investors a majority ownership. Later stage venture capital investing, however, may be associated with somewhat lower target rates (Fenn, Liang and Prowse 1997).

${ }^{14} \mathrm{Barry}$ et al. (1990) reported that venture capitalists enjoyed positive returns in $96 \%$ of the cases in which one of their funded firms was taken public via an IPO. However, for the next most common (and next most attractive) exit, acquisition by another company, only 59\% provided positive returns to venture capitalists.
} 
the increment of funds that an angel wishes to invest in a small firm is often consistent with the amount that the firm needs. Quite often one angel is sufficient, so redundancy of information production is not a relevant issue. Angels typically provide finance in a range of about $\$ 50,000$ to $\$ 1,000,000$, below that of a typical venture capital investment (Wetzel, 1994).

However, angels do not always act alone. Angels sometimes work as a small investment group where they coordinate their investment activity (Prowse 1998). Sometimes this is done in conjunction with a "gatekeeper" such as a lawyer or accountant who brings deal flow to the group and helps structure the contracts. The angel market tends to be local, where investor proximity may be important in addressing information problems.

There is disagreement over the extent to which angels are active investors. Barry (1994) described angels as investors who do not "[take] on the consulting role of venture capitalists." In contrast, Wetzel (1994) reported that "angel deals typically involve a close group of co-investors led by a successful entrepreneur who is familiar with the venture's technology, products, and markets." Wetzel further noted that the advice and counsel that angels provide to entrepreneurs can be quite important. Some suggest that angels are willing to accept psychic return partially in lieu of monetary return and develop relationships with their entrepreneurs over time. Angels often invest in multiple rounds at different stages as the companies they are investing in move through the early stages of financial growth. Overall, the degree to which angels are active investors and the extent to which psychic return partially offsets monetary return are substantially unresearched questions. It is safe to say, however, that angels demand less control and bring less financial expertise to the table on average than venture capitalists.

While the angel market can best be characterized as informal, there have been some attempts to formalize the market. These attempts may be motivated by the assumption that search and information costs have been significant impediments to the efficiency of the angel market. One thrust has been to create private angel networks in which entrepreneurs can solicit equity investments by angels who are members of the network. Typically the network is operated by a not-for-profit entity (such as a university), sometimes referred to as the "switch." The entrepreneurs solicit private equity by displaying summary information about their firm and their financial needs in the form of term sheets on the network. Angels who have been 
"qualified" by the switch can then search across these term sheets and identify companies of interest. The angel is then put in touch with the entrepreneur to discuss the investment opportunity. Recently the Small Business Administration (SBA) has linked a number of angel capital networks together to form a system called ACE-Net. This system now permits angels to search across term sheets from entrepreneurs across the U.S. (Acs and Tarpley 1998, Lerner 1998a).

The value of angel networks in general, and ACE-Net in particular, is a substantially unresolved issue. The networks are typically subsidized and are predicated on the assumption that there is some degree of market failure in the angel market. However, the existing informal nature of the angel market may be the optimal solution to the acute information problems associated with early stage new venture financing. The role played by gatekeepers, for instance, may be quite important in reducing information-driven contracting costs. For example, an accountant may have both an entrepreneur and an angel as clients. In connecting the two, the accountant has reputational capital at stake and thus provides some of the services associated with classic intermediation. It is unclear whether a more formal market for angel finance can provide an economically significant substitute or addition to the current informal angel market. ${ }^{15}$

\section{The Venture Capital Market}

Unlike the angel market, the venture capital market is intermediated. ${ }^{16}$ Venture capitalists perform the quintessential functions of financial intermediaries, taking funds from one group of investors and redeploying those funds by investing in informationally opaque issuers. In addition to screening, contracting, and monitoring, venture capitalists also determine the time and form of investment exit (Tyebjee and Bruno 1984, Gorman and Sahlman 1989). In performing these functions, the venture capitalist is the consummate active investor, often participating in strategic planning and even occasionally in operational decision making.

Interest in the relationship between the venture capital fund and its portfolio investments is reflected

\footnotetext{
${ }^{15}$ The other recent thrust in the angel market has been the standardization of documentation. In conjunction with the ACE-Net project, the SBA has adopted standardized legal forms for angel private equity contributions (available on its website), which may lower transactions costs.

${ }^{16}$ For more extensive reviews of the venture capital literature, see Barry (1994) and Fenn, Liang, and Prowse (1997).
} 
in a growing body of research on this subject, spurred in part by the development of new databases (Fenn and Liang 1998). This research includes investigations of origination and due diligence, the nature of the contract between the venture capital fund and the firms it invests in, and how institutional features of the market affect these investments. At origination, venture capitalists confront a significant adverse selection problem associated with providing external finance to unusually opaque firms and therefore spend a considerable amount of time evaluating prospective issuers (Amit, Glosten, and Muller 1990, Fried and Hisrich 1994, Fenn, Liang and Prowse 1997). Syndication may also help solve the adverse selection problem (Lerner 1994a).

An agency problem arises in the relationship between the entrepreneur and the venture capitalist in which the entrepreneur may expend insufficient effort, exhibit expense preference behavior, or lack sufficient information or skill to make optimal production decisions. The problem may be compounded by the fact that information in general about the value of the project is imperfect and revealed over time (Cooper and Carleton 1979, Bergemann and Hege 1998). The menu of contract features that characterize venture capital investing may be explained as solutions to this agency problem. These include the staging of venture capital investments to assure optimal exercise of production options and efficient stopping (Sahlman 1988, 1990, Chan, Siegel, and Thakor 1990, Admati and Pfleiderer 1994, Gompers 1995, Bergemann and Hege 1998), ${ }^{17}$ control and the choice of equity/debt instrument (Gompers 1993, Marx 1993, Cornelli and Yosha 1997, Trester 1998), entrepreneur compensation (Sahlman 1990), restrictive covenants (Chan, Siegel, and Thakor 1990, Gompers and Lerner 1996), board representation (Lerner 1995), and the allocation of voting rights (Fenn, Liang, and Prowse 1997). In addition, venture capitalists expend considerable resources monitoring their portfolio firms (Gorman and Sahlman 1989), and they often tend to specialize in particular industries where they develop expertise (Ruhnka and Young 1991, Gupta and Sapienza 1992, Norton and Tenenbaum 1993).

About $80 \%$ of all venture capital in the U.S. flows through independent limited partnerships, with most of the remaining $20 \%$ provided by subsidiaries of financial institutions. In the partnerships, the general

\footnotetext{
${ }^{17}$ Staged finance may also create perverse incentives by encouraging the entrepreneur to focus on shortterm goals instead of wealth maximization (Hellman 1993).
} 
partners usually consist of senior managers of venture capital management firms and the limited partners are institutional investors. ${ }^{18}$ The biggest categories of institutional investors are public pension funds (26\%), corporate pension funds (22\%), commercial banks and life insurance companies (18\%), and endowments and foundations (12\%) (Fenn, Liang, and Prowse 1997). The limited partners typically put up 98\% or more of the funds and receive $80 \%$ of the partnership's profits. The general partners receive $20 \%$ of the partnership's profits plus a fee for managing the fund. ${ }^{19}$

The limited partnership is structured to address problems of asymmetric information and to align the incentives of the general partners and the limited partners. This is accomplished particularly through the finite-life nature of the partnership agreement, which requires general partners to regularly raise new funds in order to stay in business, and the linking of the general partners' compensation to the success of the partnership. Other features include covenants restricting the venture capitalist's management of the fund, mandatory distribution requirements, and other restrictions on activities that may be associated with selfdealing (Sahlman 1990, Gompers and Lerner 1996).

The typical venture capital fund has a 10 year life span, usually with an option to extend for two years. Large, well-established venture capital management firms operate multiple funds simultaneously, each at different stages in their life spans. During the early years of the fund, the senior managers search for and screen new deals, and structure the contracts with the selected companies. During the middle years, the venture capitalists manage the investments in their fund's portfolio. This is associated with active involvement in the management of each of the portfolio companies, including providing consulting services and sometimes becoming involved in solving major operational problems, serving on the board of directors, finding and hiring managers, occasionally replacing poorly performing managers, and assisting the firm in forming strategic alliances. Gorman and Sahlman (1989) found that these activities were associated with venture capitalists allocating more than 100 hours and visiting each of their portfolio firms on average 19

${ }^{18}$ This is an oversimplification of the precise legal relationship among the senior managers, the management firm, and the venture capital fund. See Fenn, Liang, and Prowse (1997) for more details.

${ }^{19}$ See Gompers and Lerner (1994a) and Fenn, Liang, and Prowse (1997) for more detail on the specific structure of limited partnerships and associated compensation issues. 
times per year.

During the later years of a fund's life, much of the venture capitalist's time is focused on "harvesting" portfolio firms. The most attractive exit is typically through an IPO and subsequent public offerings. The IPO market is characterized by the same type of informational asymmetries that characterize the private equity market, although firms going public are generally less opaque than when they received infusions of angel finance and venture capital. Mechanisms such as underpricing (Rock 1986, Benveniste and Spindt 1989) and price stabilization (Chowdhry and Nanada 1996, Benveniste, Busaba and Wilhelm 1996, Benveniste, Erdal, and Wilhelm 1998) are market features that address information problems. Venture capitalists may also play a role in reducing opacity. Megginson and Weiss (1991) found that venture capitalbacked IPOs are less underpriced than nonventure-backed IPOs, Barry et al. (1990) found that the degree of underpricing is negatively related to the amount of venture capital ownership, and Brav and Gompers (1997) found that venture capital-backed IPOs out perform nonventure-backed IPOs in the long run. In addition, the venture capitalist may add value choosing optimal timing for an IPO (Lerner 1994b). However, less reputable venture capitalists may have incentives to bring portfolio firms to market too early, possibly to help fund-raising efforts associated with starting new funds (Gifford 1994, Gompers 1996).

In general, only a minority of the firms in the fund's portfolio will be successful enough to take public. The second best exit is by sale to another company. Alternatively, if a portfolio firm does not do well, it may be put back to its original owners, or (in a worst-case scenario) liquidated. However, the payoffs from the few most successful firms generally provide the bulk of the fund's returns.

\section{The Role of Private Debt Markets in Small Business Finance}

We next turn to the private debt markets that finance small business. As discussed above, the capital structure decision between equity and debt is different for small firms than for large firms in part because small businesses are usually more informationally opaque than large firms. In addition, since small businesses are usually owner-managed, the owner/managers often have strong incentives to issue external debt rather than external equity in order to keep ownership and control of their firms.

Table 1 shows estimated percentage distributions of nine different types of private debt for U.S. small business, three each from the major categories of financial institutions, nonfinancial business and 
government, and individuals. Financial institutions account for $26.66 \%$ of the total funding of small businesses, or slightly more than half of the total debt funding of $50.37 \%$, with commercial banks providing the lion's share at $18.75 \%$. Nonfinancial business/government debt provides $19.26 \%$ of small business funding (mostly trade credit), and debt owed to individuals accounts for only $5.78 \%$ of small business funding. After briefly discussing the latter two categories, we will spend most of the section discussing research on financial institution debt.

\section{Nonfinancial Business and Government Debt}

A sizable $15.78 \%$ of total small business assets are funded by trade credit, as measured by accounts payable at the end of the prior year. Clearly, trade credit is extremely important to small business finance, but has received much less research interest than commercial bank lending, which provides only slightly more credit to small business. Although relatively expensive, a small amount of trade credit may be optimal from the viewpoint of transactions costs, liquidity, and cash management and may help give the borrowing firm and supplier information that helps predict cash flows (Ferris 1981).

It is not necessarily clear, however, whether working capital finance is best provided by suppliers versus by a financial institution through a line of credit. In some cases, suppliers have advantages over financial institutions because they may have better private information about the small business' industry and production process, or may be able to use leverage in terms of withholding future supplies to solve incentive problems more effectively (Biais and Gollier 1997). Suppliers may also be better positioned to repossess and resell the supplied goods (Mian and Smith 1992).

Trade credit may also provide a cushion during credit crunches, monetary policy contractions, or other shocks that leave financial institutions less willing or less able to provide small business finance (Nilsen 1994, Biais and Gollier 1997). During these times, large businesses may temporarily raise funds in public markets, such as commercial paper, and lend these additional funds to small businesses through trade credit (Calomiris, Himmelberg, and Wachtel 1995).

Trade credit that extends beyond a few days of liquidity, however, is often quite expensive. A typical trade credit arrangement makes payment due in full in 30 days, but gives a $2 \%$ discount if payment is made within the first 10 days (Smith 1987). The implicit interest rate of $2 \%$ for 20 days (although it is not 
always strictly enforced) is much higher than rates on most loans from financial institutions, and so would likely only be taken in cases in which credit limits at financial institutions are exhausted. As we will see shortly, only about half of small businesses have loans from financial institutions, so very expensive trade credit may often be the best or only available source of external funding for working capital. Prior empirical analysis found that both transactions and financial variables affect the proportion of trade credit that is paid late by small businesses (e.g., Elliehausen and Wolken 1993). It has also been found in the U.S. that as a small business ages and its relationships with financial institutions mature -- and it presumably becomes more informationally transparent -- it tends to pay off its accounts payable sooner and become less dependent on trade credit (Petersen and Rajan 1994, 1995). Recent evidence from Russia suggests that in developing economies, trade credit provides a signal that leads to more bank credit (Cook 1997). This suggests that in economic environments with weak informational infrastructure and less developed banking systems, trade credit may play an even more important role because of its strength in addressing information problems.

The data in Table 1 suggest that direct loans from nonfinancial businesses and government are both small, just $1.74 \%$ and $0.49 \%$ of small business funding, respectively. However, the government does provide financial support in other ways. For example, the SBA had guarantees outstanding on 135,859 small business loans totaling $\$ 21.2$ billion as of September 30,1994 , or about $1.27 \%$ of all U.S. small business finance (although these data are from a slightly different point in time from the data in Table 1) (U.S. Small Business Administration 1995, p. 281).

\section{Small Business Debt Held by Individuals}

Turning to debt held by individuals, these loans account for just $5.71 \%$ of total small business finance. Most of this (4.10\%) represents debt funding from the principal owner in addition to his/her equity interest in the firm. In some cases, these personal loans may be just a convenient way of providing short term finance to the firm, while in other cases, these loans may create tax benefits by substituting interest for dividends. The amount of funding raised through credit card financing -- which has received much press attention as a potential alternative to conventional bank loans (e.g., Ho 1997) -- appears to be quite small, just $0.14 \%$ of total small business finance. However, this figure may be understated because it includes only the amount of debt carried after the monthly payment is made, neglecting short-term float between the 
purchase date and the monthly payment. Finally, $1.47 \%$ of small business funding is provided by loans from other individuals, most of which is likely from family and friends or other insiders.

\section{Financial Institution Debt}

For the remainder of this section, we will focus on banks, finance companies, and other financial institutions that together provide most of the external debt finance to small businesses. As noted above, these financial institutions specialize in screening, contracting, and monitoring methods to address information and incentive problems, and we will cover a few of the most important of these methods in the limited space here.

Table 2 helps illustrate some of the facts about these financial institutions and their methods. Panel A shows that only a little over half of small businesses, $54.23 \%$, have any loans or leases from financial institutions. The data also suggest that small firms tend to specialize their borrowing at a single financial institution -- only about one-third of the borrowing firms $(19.30 \% / 54.23 \%)$ have loans from two or more institutions. In $86.95 \%$ of the cases, small businesses identify commercial banks as their "primary" financial institution, since banks dominate other institutions in providing transactions/deposit services, and also provide most of the loans to the small businesses that receive financial institution credit $(40.57 \% / 54.23 \%){ }^{20}$ The data in Panel B suggest that small businesses tend to stay with their financial institutions. On average, small firms have been with their current financial institutions for 6.64 years, and 9.01 years for their primary institution. The findings in Panels A and B -- that small businesses tend to get their credit from a single institution and that they stay with their institutions for long periods of time -- suggest benefits to these relationships, which are discussed below.

Panel $\mathrm{C}$ gives information on the type of loan or lease. Most of the funds, $52.03 \%$, are drawn under lines of credit, a type of loan commitment. Such commitments are promises by the financial institution to provide future credit, and may be used to reduce transactions costs, provide insurance against credit rationing, and other purposes described below. Mortgage loans, the next largest category at $13.89 \%$, may be secured by either commercial property or personal property of the owner. For most equipment loans,

\footnotetext{
${ }^{20}$ Banks and finance companies also tend to differ in their lending policies possibly in part because of regulatory differences. Based on data for large borrowers, finance companies fund observably riskier, more highly levered borrowers on average than banks, but both cover the same risk spectrum (Carey, Post, and Sharpe, forthcoming).
} 
motor vehicle loans, and capital leases, the proceeds of the loan or lease are used to purchase the assets pledged as collateral. Panel D shows that $91.94 \%$ of all small business debt to financial institutions is secured. This very high percentage implies the vast majority of virtually all types of financial institution loans and leases to small businesses -- including loans drawn under lines of credit -- are backed by collateral. In addition, $51.63 \%$ of financial institution debt is guaranteed, usually by the owners of the firm. The data in Table 2 as a whole suggest that financial institutions use a number of contracting methods like collateral and guarantees, lines of credit, and relationships extensively to deal with the information and incentive problems of small businesses, and we next investigate some of these methods in depth. ${ }^{21}$

Collateral and Guarantees. Collateral and guarantees are powerful tools that allow financial institutions to offer credit on favorable terms to small businesses whose informational opacity might otherwise result in either credit rationing or the extension of credit only on relatively unfavorable terms. These contract features address adverse selection problems at loan origination and moral hazard problems that arise after credit has been granted. Collateral and guarantees may also reduce the cost of intermediation because a financial institution may be able to assess the value of pledged or guaranteed assets at lower cost than it can assess the value of the business as an on-going concern.

We distinguish between "inside" collateral and "outside" collateral. Inside collateral involves pledging assets owned by the firm. This reorders the claims of the firm's creditors by giving one of them priority via a security interest in specific assets. Outside collateral involves pledging assets owned outside the firm, typically assets belonging to the firm's owners. Outside collateral enhances the claim of a single creditor by conveying recourse against additional assets outside the firm without diminishing the claims of the other creditors in the event of bankruptcy.

Guarantees give the lender general recourse against the assets of the principal owner or other party issuing the guarantee for deficiencies by the firm in repaying the loan. A guarantee is similar to a pledge of outside personal collateral, but differs in two important ways. First, a guarantee is a broader claim than a

\footnotetext{
${ }^{21}$ The NSSBF also has information on the race and gender of the entrepreneur, which allows for analysis of possible race and gender discrimination. Research in this field is just beginning, but there does appear to be some evidence of racial discrimination by lenders (Cole 1997, Cavalluzzo and Cavalluzzo forthcoming).
} 
pledge of collateral, since the liability of the guarantor is not limited to any specific assets. Second, a guarantee is a weaker claim than a pledge of collateral against any given set of assets, since a guarantee does not involve specific liens that prevent these assets from being sold or consumed. ${ }^{22}$

Both guarantees and outside personal collateral may provide powerful incentives for the entrepreneur to behave in a way that benefits the beneficiary creditor (often to the detriment of other creditors) when the business is in distress. This incentive depends more on the disutility to the entrepreneur of losing personal assets, rather than on the value of the attachable assets to the lender in the event of default. Thus, a guarantee or pledge of personal collateral from an entrepreneur with only a modest amount of personal wealth may still provide a strong incentive that benefits the lender, even if recourse against these personal assets represents only a small fraction of the value of the loan.

Most of the research on collateral has emphasized its use in mitigating information problems. Theory suggests that pledging outside collateral may help resolve adverse selection problems when the borrower has more information about the quality of the investment than the lender, and may help prevent credit rationing (Stiglitz and Weiss 1981, 1986, Bester 1985, Chan and Kanatas 1985, Besanko and Thakor 1987a,b). Similarly, pledging outside collateral may attenuate moral hazard by reducing the incentives to switch into riskier projects or to reduce effort (Boot, Thakor, and Udell 1991). Models of inside collateral similarly key on information problems and incentives. The pledging of some of the firm's assets to one debt holder may help mitigate Myers' (1977) underinvestment problem by allowing the firm to invest in relatively safe projects (Stulz and Johnson 1985), may reduce asset-substitution problems (Smith and Warner 1979), may help enforce optimal firm closure (Swary and Udell 1988), may help in the enforcement of covenants and renegotiating the loan under financial distress (Gorton and Kahn 1997), or may help reduce the costs of dividing the remaining assets in bankruptcy (Welch 1997), although it may exacerbate the agency costs of debt by discouraging maintenance of secured assets (John, Lynch, and Puri 1997).

Some models also take into account the effects of collateral on the costs of other types of funding.

\footnotetext{
${ }^{22}$ Personal outside collateral and guarantees, while commonly used by small businesses, are rare for large firms. Usually no owner of a large corporation has enough wealth to back the debt of the firm or owns enough of a share of the firm to want to back the debt personally.
} 
For example, a firm may choose to borrow on an unsecured basis from a financial institution rather than pledging collateral because unsecured lending may require more monitoring by the institution, which as discussed above may reduce the costs of other equity and debt (Adler 1993). The choice of unsecured debt might also be used as a signal of a favorable quality assessment by the lender, again reducing the costs of other equity and debt (Rajan and Winton 1995).

Much of the theoretical and empirical analysis in this literature concerns whether riskier versus safer borrowers tend to pledge collateral, and the extent to which pledging collateral reduces risk, which may be of policy concern for the prudential supervision of financial institutions. Theoretical models of collateral usually start with the assumption of informational opaqueness and analyze whether riskier versus safer borrowers within an observationally equivalent risk pool will pledge collateral more often. There is disagreement in the results. Most of the models of outside collateral find that safer borrowers within the pool will tend to pledge outside collateral because the owner/managers of safer firms know they are less likely to lose their collateral (reducing adverse selection problems) or because pledging collateral induces them to plot a safer course of action (reducing moral hazard problems). The relatively few models of inside collateral are either ambiguous with respect to risk or predict that riskier firms are more likely to pledge collateral. The practitioner literature is typically focused on inside collateral and its association with observable risk (rather than differences in risk known only to the borrowers). This literature usually predicts that financial intermediaries will more often require riskier borrowers to secure their loans (Hempel, Coleman, and Simonson 1986, Morsman 1986). The empirical literature usually found secured lending associated with risky borrowers or with risky loans (which implies risky borrowers, since the collateral itself reduces the risk of the loan) (Orgler 1970, Hester 1979, Scott and Smith 1986, Berger and Udell 1990,1992, Booth 1992, Booth and Chua 1996, Klapper 1998).

Most of the empirical literature was written without access to data on small business firms. A new set of studies on collateral and guarantees uses the data from the NSSBF, NFIB, and SCF to focus on the types of collateral and guarantees used by small businesses and the extent to which these tools are used to address informational opacity of these firms.

Many small businesses pledge accounts receivable and/or inventory as inside collateral to secure 
lines of credit in which the amount of credit granted fluctuates with the value of qualifying receivables/inventory. ${ }^{23}$ This may be particularly useful for an informationally opaque small firm because the lending institution's risk exposure is not as closely tied to the uncertain future cash flows of the firm as in other types of lending. The monitoring of receivables/inventory may also produce valuable information about future firm performance as well as information about the value of the collateral, and therefore be used as part of an overall relationship that may lead to more favorable credit terms in the future. It has been found that accounts receivable and/or inventory was pledged twice as often as all other types of collateral combined on bank lines of credit to small business and that small firms that pledge accounts receivable and/or inventory were younger and had shorter relationships with their lenders, consistent with informational opacity (Berger and Udell 1995).

Outside personal collateral and guarantees may also be important to the financing of small firms that are informationally opaque and have few pledgeable business assets. About $40 \%$ of small business loans and close to $60 \%$ of loan dollars are guaranteed and/or secured by personal assets (Ang, Lin, and Tyler 1995, Avery, Bostic, and Samolyk 1998). Combining the NSSBF data with the personal wealth data from the SCF, it was found that the use of personal collateral and guarantees occurred more often 1) for firms that were younger, smaller, and had fewer tangible assets (and are arguably more informationally opaque); and 2) for owners that were wealthier, particularly with more liquid assets (Avery, Bostic, and Samolyk 1998). This is also another example of how the personal finances and business finances of small business owners are often intertwined. ${ }^{24}$

\footnotetext{
${ }^{23}$ Secured lending which is principally based on the value of the specific assets pledged as inside collateral (as opposed to the projected cash flows of the firm) is often referred to as asset-based lending.

${ }^{24}$ Personal guarantees and pledges of personal assets may be seen as substitutes for an injection of additional equity by the owners. Under most circumstances, financial institutions would offer better terms if the same amount of equity were added to the firm, which would save the costs of pursuing recourse against personal assets in the event of financial losses. However, these extra costs may be offset by some benefits for the owner of personal collateral and guarantees, such as better convenience, lower transactions costs, or better diversification, rather than liquidating personal assets (e.g., private home) and investing the proceeds in the business. The data generally support the dominance of personal equity over personal collateral and guarantees -- equity makes up about $85 \%$ of small business owners' investments in their businesses as opposed to only about $10 \%$ for personal collateral/guarantees, and about $5 \%$ for personal loans to the business (Avery, Bostic, and Samolyk 1998).
} 
Other analyses of small business that could not distinguish between inside and outside collateral are also consistent with the notion that more informationally opaque or riskier small businesses more often pledge collateral. For example, an analysis using the NFIB data on all types of collateral (both personal and business) found that younger firms tended to pledge collateral more often (Leeth and Scott 1989). It was also found that small businesses from the former East Germany tend to pledge collateral more often than firms from the former West Germany, presumably due at least in part to greater informational opacity or higher risk of the firms in the former East Germany (Harhoff and Korting 1997).

Loan Commitments/Lines of Credit. Another set of contract features that may be employed to help offset the information problems of small businesses is loan commitments or lines of credit from financial institutions. A loan commitment is a forward contract issued by a financial institution to provide debt under prespecified terms over some future time interval unless the borrower's condition has suffered "material adverse change," or if the borrower has violated a covenant in the contract. As shown in Table 2 above, most small business debt held by financial institutions is under lines of credit, which is a form of loan commitment. Lines of credit are generally pure revolving credits that allow the firm to borrow as much of the line as needed at any given time over the time interval specified. Lines of credit are thus very flexible and convenient for the borrower, and are usually used to provide working capital, rather than to fund specific large investments.

Loan commitments provide protection for the borrower against credit rationing or credit crunches that are based on general market conditions, rather than specific, identifiable, legally defensible deteriorations in the individual borrower's condition (Melnik and Plaut 1986, Sofianos, Wachtel, and Melnik 1990, Avery and Berger 1991a, Berger and Udell 1992, Morgan 1994, 1998). This implies that most borrowers are essentially immune -- at least until their current commitment contracts expire -- from having their credit withdrawn in general credit rationing or credit crunch episodes.

Commitment contracts may either help resolve adverse selection/moral hazard problems or exacerbate these problems. By offering potential borrowers various sets of contract terms on commitments -up-front fees, usage fees, interest rates, etc. -- financial institutions may be able to induce informationally opaque borrowers to reveal their types, or to choose higher net present value projects (Boot, Thakor, and 
Udell 1987, Kanatas 1987, Thakor and Udell 1987, Berkovitch and Greenbaum 1991). However, commitments can also exacerbate information problems because commitment contracts are signed at an earlier time when less information is available than spot loan agreements,. By agreeing to provide credit in advance, it is possible that the financial institution would have gained enough information by the time the funds are drawn down to refuse to issue a spot loan on similar terms or that the borrower would be able to risk-shift to take advantage of the financial institution (Avery and Berger 1991a).

Similar to the collateral research, most of the empirical commitment research focused on the risk associated with loans under commitment relative to the risk of other loans. No strong association between commitments and risk was found when commitments to all sizes of business borrowers were examined (Koppenhaver 1989, Avery and Berger 1991a,b, Berger and Udell 1990, 1993) or when just commitments to small businesses were examined (Berger and Udell 1996). Additional research results about lines of credit issued to small businesses are discussed below.

Debt Covenants and Maturity. Another set of tools that financial institutions use in debt contracts to solve the informational opacity problems of small businesses include restrictive covenants and choice of maturity. The debt contracts issued by commercial banks, finance companies, and other financial institutions are often covenant-rich, requiring the borrower to return to the institution to renegotiate these covenants when strategic opportunities to enhance value arise or when the financial condition of the firm changes (Berlin and Loeys 1988, Carey et al. 1993). In part, these covenants and their renegotiation are intended to give the lending institution more control and prevent borrowers from engaging in risk-shifting behavior. By using specific financial ratio and activity restrictions linked to periodic submission of financial information, covenants limit the firm's ability to change its financial condition or strategy. Thus, covenants can force a borrower to obtain permission from its lender before embarking on significant strategic changes. One theoretical result is that the strictest covenants are expected to be placed on the firms with the most credit risk and greatest moral hazard incentives (Berlin and Mester 1993). As discussed below, however, effective covenants generally cannot be imposed on the smallest firms which do not have audited financial statements, so short maturities must be used in place of formal covenants to control the behavior of these firms.

A borrower can request a waiver when a covenant prevents the firm from engaging in a new activity. 
Renegotiation about the waiver allows the lender considerable control over whether the new activity will be undertaken and under what terms. This control can be efficient in allowing positive net present value activities to be undertaken and preventing those with negative values, but inefficient outcomes can also be created by this control. For example, the control provided by covenants may allow the lender to "hold-up" the borrower for a higher rate or other concessions, even on a positive net present value project. Thus, covenants can create excessive market power and suboptimal outcomes in much the same way as can proprietary access to information acquired during relationships (discussed below).

Of course, the market limits this control by the financial institution. Most commercial bank loans can be prepaid without penalty, so borrowers have the option of obtaining more accommodating finance elsewhere (and incurring some associated transactions costs). A financial institution also has an incentive and ability as a repeat player to acquire a reputation for fairness in renegotiation.

Covenants are common in commercial bank loans and are generally stricter than those in private placements and much stricter than those in public bonds. In part, this reflects the comparative advantages of financial institutions in renegotiating and selectively relaxing these covenants (Berlin and Mester 1993). The covenants in bank loans and private placements are typically set sufficiently tightly that renegotiation is fairly likely. One study found that $47 \%$ of private placements required renegotiation one or more times over the maturity of the contract (Kwan and Carleton 1993). We are not aware of any hard data on the frequency of covenant renegotiation for bank loans, but anecdotal evidence suggests that bank loans with covenants are renegotiated even more frequently than private placements (Carey et al. 1993).

The use of covenants on small business loans is a very underresearched field, but there is some empirical evidence on the use of covenants in bank lending to larger firms. An empirical analysis of midsized firms confirms the positive role of covenants in bank loan agreements in making external funding available at reasonably low cost. It was found that the investment expenditures of firms with bank loan commitments carrying strong covenants were less sensitive to cash flow than firms with loan commitments carrying weak covenants or those without commitments (Morgan 1995). It was also found that the bank loans and commitments to mid-sized and large firms that were syndicated most broadly tend to carry the most covenants, suggesting that covenants play a positive role in assuring other syndicate members that sufficient 
controls on firm behavior are in place or that members will be informed of changes in firm condition when covenants waivers are negotiated (Carey 1996).

The choice of debt maturity is similarly used by financial institutions as a contract feature to address control and information problems. The longer the agreement, the greater the opportunity for the borrower to alter its risk profile and/or suffer financial distress. Maturity can be viewed as a particularly strong type of covenant. With a sequence of short-maturity credits, a lender can force renegotiation frequently. In contrast, with covenants renegotiation can only be triggered by those covenants enumerated in the loan agreement. One reason that smaller firms typically have less access to longer maturity debt is that they tend to be more both informationally opaque and more risky than large firms, which would create more severe problems of risk-shifting for small firms in long-term lending agreements. In addition, very small firms do not have audited financial statements, making it extremely difficult to impose ratio-related financial covenants that typically accompany intermediate and long term bank debt. ${ }^{25}$

Relationship Lending. Under relationship lending, information is gathered by a financial institution through continuous contact with the firm and entrepreneur in the provision of multiple financial services. This information is then used to help make additional decisions over time about the evolution of contract terms and monitoring strategies. The information produced in conjunction with the relationship may be garnered over time in conjunction with the extension of credit (e.g., Petersen and Rajan 1994, Berger and Udell 1995), the provision of deposit services (e.g., Allen, Saunders, and Udell 1991, Nakamura 1993, Cole 1998), or the delivery of other financial services to the firm or to the entrepreneur. This information production can occur over a much longer period of time than any one debt contract or deposit account. As shown in Table 2 above, the existing relationships between small businesses and their primary financial institutions have lasted for over 9 years on average. The vast majority of small businesses identify their commercial bank as their primary institution, presumably because banks provide the widest range of credit, deposit, and other related services. Relationship lending may have a number of benefits to small business, including lower cost or greater availability of credit due to efficient gathering of information, protection

\footnotetext{
${ }^{25}$ For a comprehensive survey on debt maturity, see Ravid (1996).
} 
against credit crunches, or the provision of implicit interest rate or credit risk insurance.

Information garnered over time in conjunction with a series of loans may be derived from the accumulation of a repayment history, periodic submissions of financial statements, renegotiations and other visits with management, and other data associated with on-going monitoring of the borrowing firm. Deposit accounts provide further information in the form of balance information, transactions activity, payroll data, etc. that help give a more complete picture of the financial health of the firm. Information about the quality of the entrepreneur may also be culled from the provision of personal loans, credit cards, deposit accounts, trust accounts, investment services, etc., and from other business dealings or personal contact outside the firm. Knowledge of the local community gained over time may also be valuable because it allows the bank to judge the market in which the business operates, to obtain references and feedback on borrower performance, and to evaluate the quality of the firm's receivables. Consolidating the purchase of financial services within a single bank may substantially strengthen the relationship, as well as increasing the sources of revenue to the bank. Frequently, this is an explicit requirement imposed by banks on their small business customers.

Under relationship lending, the bank arguably has some market power over the information gained during the relationship -- otherwise the borrower may switch to another lender if the bank tries to recoup its investment in information production when pricing the credit or other services. This market power may come from exclusive access to the information if rival lenders cannot appropriate the information culled by the bank from the deposit and loan accounts of the firm and the entrepreneur. Alternatively, the market power may come from long-term contracting, such as long term loans (which small businesses typically do not have). Market power may also derive from substantial switching costs that prevent the borrowing firm from leaving when faced with above-competitive prices, which is more likely to occur, the more tailored the services provided by the bank. Finally, market power may come from limits on competition in the lending and deposit markets, such as those that might characterize highly concentrated rural banking markets.

Ironically, market power by the bank may play a positive role for the small business customer by allowing the bank to enforce long-term implicit contracts in which the borrower receives a subsidized interest rate in the short term, and then compensates the bank by paying a higher-than-competitive rate in a later 
period (Sharpe 1990). As the market power of the bank increases, small businesses with progressively lower credit quality may be able to obtain funding (Petersen and Rajan 1995).

However, excessive exploitation of market power can also create other problems. These problems may include the establishment of multiple banking relationships by borrowers to avoid exploitation, which can create higher transactions costs, duplicated effort, free-rider problems, etc: Market power may also lead to increased agency costs (greater risk-taking, reduced managerial effort) because of high rates. In addition, some small businesses with positive net present value investment opportunities may simply choose not to borrow and invest in order to avoid future exploitation by the lender. These problems may be reduced by the use of loan commitments that limit the ability of a bank to exploit a borrower later in the relationship by prespecifying contract terms (Houston and Venkataraman 1994). The tradeoff between the beneficial effects of the efficient gathering of information though the relationship versus the potential problems created by the exploitation of this market power is one of the central issues in relationship lending research.

Some of the adverse incentive effects of market power over relationship information may be mitigated by the release of some of this information. Padilla and Pagano (1997) showed that banks may increase their profits by sharing some of their private information about the condition of a small business (e.g., by giving this information to a credit bureau). Essentially, by giving away information and profits in future periods, the bank may make higher current profits by encouraging additional entrepreneurial effort. The logic of Padilla and Pagano's model may be extended to other problems created by market power. In many circumstances, it may be in the bank's interest to reveal information learned through relationship lending with a lag. The bank may be able to earn some rents off the information in the short term and demonstrate to the small business that it will not be exploited in the long run.

The use of a single relationship bank by a small business may also create a problem in which having credit withdrawn by the bank may signal unfavorable information about the small business, even if there has been no deterioration in the condition of the small business. This may occur because the bank experiences its own liquidity problem, which cannot be distinguished from an individual borrower's credit problem. As a result, small businesses may maintain multiple banking relationships, creating higher transactions costs. Detragiache, Garella, and Guiso (1997) showed that this problem may be particularly severe in economies 
in which bankruptcy costs are high (so greater costs are borne if the borrower is unfunded) and in which banks rarely have liquidity problems (so that a withdrawal of credit by one bank is more likely to be interpreted by others as a credit problem for the borrower). They suggested that these conditions hold more closely in Italy than in the U.S., which may help explain why Italian small businesses have a mode of 7 banking relationships and U.S. small businesses have a mode of 1 banking relationship (their Table 1).

The benefits and costs of relationships have been shown to some degree in empirical research using data on large business. For example, the "bank uniqueness" literature suggests that banking relationships offer important benefits even for firms that are sufficiently informationally transparent as to have publicly traded equity. Studies found that announcements of bank loan commitments and similar credit facilities yield abnormal positive stock returns on average for the borrowing firms (Mikkelson and Partch 1986, James 1987, Lummer and McConnell 1989, Billett, Flannery, and Garfinkel 1995, Klapper 1998). ${ }^{26}$ These results suggest that the banking relationships embodied by these commitments add value, and that the creation of this value is signaled to market participants. By extension, if relationships are valuable for large, relatively transparent firms, they are likely even more valuable for small, relatively opaque firms.

Other research on large firms suggests that the "hold-up" problem discussed above -- in which the bank may exploit market power over the borrower subsequent to information production -- may also apply to firms with access to public debt markets. Some research suggests that these firms may try to reduce the control of their banks by issuing public debt, even though public debt may entail higher costs (Diamond 1991, 1993, Rajan 1992, Houston and James 1996). These large firms may also engage in multiple banking relationships in order to obtain additional needed funding that might otherwise be withheld by a single bank with monopoly access over relationship information (Houston and James 1996). ${ }^{27}$ Presumably, if market power by a single relationship bank is a significant problem for large, informationally transparent firms that

\footnotetext{
${ }^{26}$ The size of the effect found depended upon the type of institution issuing the contract (bank, finance company, insurance company issuing a private placement, etc.), whether the contract was a new commitment or a renewal, the credit rating of the issuing institution (commitments from higher-rated institutions yielding greater excess returns), and whether the line was secured (higher return for secured lines).

${ }^{27}$ One solution intermediate between single- and multiple-relationship banking is to have a special relationship with one bank while borrowing from multiple banks. An example is the "housebank" system for mid-sized borrowers in Germany (Elsas and Krahnen 1997).
} 
can issue public debt, it may be even more of a problem for small, informationally opaque firms that do not have access to public debt markets.

The relationship lending literature often focuses on whether the terms of bank lending ease or tighten over the course of the relationship as the relationship strengthens and the bank gains access to more information. The extant theory offers conflicting predictions. In Petersen and Rajan (1995), initial asymmetric information creates adverse selection and moral hazard problems in which banks charge high rates initially and reduce rates in later periods after borrower types have been revealed. Similarly, Boot and Thakor (1994) predict that borrowers pay high rates and pledge collateral early in the relationship, and then pay lower rates and do not pledge collateral later in the relationship after they have demonstrated some project success. In contrast, Greenbaum et al. (1989), Sharpe (1990), and Wilson (1993) all demonstrated conditions under which lenders subsidize borrowers in early periods and are reimbursed for this subsidy with high rates in later periods, so terms of lending for small businesses may worsen over the course of the relationship.

The empirical results on this issue are mixed. Using the 1987 NSSBF data on U.S. small businesses, it was found that interest rates and collateral requirements on lines of credit tend to decline with the length of the bank-borrower relationship for some small businesses (Berger and Udell 1995), although rates on loans generally did not decline with the length of the relationship when loans not issued under lines of credit were included (Petersen and Rajan 1994). One potential explanation for this difference is that the value of a relationship may depend on the type of credit. Lines of credit may more often be relationship-driven, whereas mortgages, equipment loans, motor vehicle loans, and other loans may more often be transactionsdriven. ${ }^{28}$ It was also found that dependence on trade credit decreased with the length of the banking relationship, supporting the value of relationship lending (Petersen and Rajan 1994, 1995). Using the 1993 NSSBF, it was found that the existence of a relationship between the small business and the bank raised the probability that credit would be extended (Cole 1998). Cole also found that the breadth of the relationship

\footnotetext{
${ }^{28}$ Supporting this notion, it was found that $88.8 \%$ of small business borrowers with lines of credit had these lines at only a single bank, where borrowers with two or more of other types of bank loans (mortgages, equipment loans, motor vehicle loans, other loans) had these loans consolidated at a single bank only about $50 \%$ of the time or less (Berger and Udell 1995).
} 
was quite important - credit was particularly likely to be extended if the firm also obtained savings account and financial management services from the same bank. Another analysis using data on two U.S. bank holding companies found no clear effect of the duration of the relationship on the rates charged to small businesses (Blackwell and Winters 1997). A study of Italian cooperative banks (which specialize in small business lending to their own members) and conventional commercial banks yielded some interesting differences depending on the type of relationship (Angelini, Di Salvo, and Ferri 1998). For small businesses that are members of cooperatives, rates decline and credit availability increases with the length of their relationship with the cooperative bank. In contrast, rates increase with the duration of the relationship for nonmember borrowers from cooperatives and for borrowers from commercial banks. A study of publicly traded Norwegian firms of varying sizes found that the probability of ending a banking relationship was higher when relationships were mature, suggesting that more information is generated early in relationships (Ongena and Smith 1997). They also found that the probability of ending the relationship was higher if the firm was young, small, and growing, presumably when relationships could do the most to overcome informational opacity problems. This may suggest either that the banks tried to exploit market power over information and drove some of these borrowers away or that the information the banks learned was often unfavorable, and banks purposely set contract terms to drive away the borrowers with unfavorable information. A study of mid-sized German firms found no association between relationship duration and loan pricing, but did find some evidence of better credit availability through stronger bank-borrower relationships (Elsas and Krahnen 1997). Specifically, Elsas and Krahnen found that the firm's "housebank" -- the bank with which the firm has its closest or strongest relationship -- was willing to provide liquidity during periods of firm distress, whereas other banks were not. A study using survey data on smaller German firms found that longer relationships were associated with lower collateral requirements, but no difference in interest rates (Harhoff and Korting 1997). However, firms that described their banking relationship as one of mutual trust in response to a survey question had both lower loan rates and lower collateral requirements.

The results in this literature suggest three tentative conclusions. First, the strength of the relationship as measured by its duration or other factors is usually, but not always, associated with easier credit terms for the small business in terms of lower rates, fewer collateral requirements, less dependence on trade credit, or 
more availability of funds. This lends support to the notion that relationship lending appears to be an efficient information collection mechanism and at least indirectly suggests that problems with the exploitation of market power are not so severe as to offset the benefits of pursuing a relationship in most cases. However, there are important exceptions. For example, most small businesses in Italy borrow from multiple banks and face higher rates as their relationships mature.

Second, there is considerable uncertainty about the exact mechanism through which banks obtain and use relationship information and how best to measure the strength of the relationship (i.e., how to proxy for the value of information obtained through the relationship). Most of the studies specified the duration of the relationship as the measure of its strength. The results of some of the studies also suggested that in addition to duration, the strength of the relationship may also depend upon 1) whether the loan is drawn under a line of credit, 2) the breadth of the relationship (whether it extends to deposits and other services), 3) the size of the borrowing firm and its outside finance options, 4) the structure of the banking industry, and 5) the trust that is built up between the bank and the small business. Further research is needed to determine how banks obtain and use the information acquired through relationships.

Third, the effects of relationships differ across nations, presumably due to differences in their macroeconomic environments in terms of information infrastructure, business conditions, and regulatory regime. The single banking relationships of small businesses in the U.S. and most other nations versus the multiple banking relationships of small businesses in Italy may be at least partially explainable by differences in the concentration of the banking industry, the fragility of the financial systems, bankruptcy rules, and other factors that affect the collection and use of information by banks. ${ }^{29}$

\section{The Vulnerability of Small Business Finance to the Macroeconomic Environment}

\footnotetext{
${ }^{29} \mathrm{~A}$ related issue is the extent to which the public reputation of the firm affects the terms of credit faced by the small business versus the private information held by the primary bank gained through relationship lending (i.e., reputation versus monitoring as in Diamond 1991). Many of the studies just reviewed also found that the age of the firm was also quite important to obtaining bank credit on easier terms. Assuming that age proxies well for public reputation, this suggests that public reputation may be of a similar order of importance as the establishment of a strong banking relationship to obtaining favorable credit terms. An additional study also found that the effect of the longest banking relationship dominated the effect of the length of the relationship of the bank with credit currently outstanding (Covitz 1997). This suggests that some of the information obtained through relationships may be appropriable by other lenders, or that the bank does not have full market power over the use of this information.
} 
The flow of funds to small business in private equity and debt markets is likely to depend in an important way upon fluctuations in the macroeconomic environment, such as shocks to the real or financial sectors or changes in government policy. Because of its informational opacity, small business arguably is likely to bear a disproportionate share of the loss of funding that occurs when there is a market failure. In this section, we consider a number of areas of research related to this vulnerability, including the effects of public equity market disruptions and public policy changes on the flow of funds into angel finance and venture capital markets, and the effects of monetary policy shocks, credit crunches, and the consolidation of the banking industry on the flow of funds to small business in banking markets.

\section{The Flow of Funds into Angel Finance and Venture Capital Markets}

Business conditions in general can affect the flow of funds in the private equity and debt markets. The flow and pricing of private equity depend crucially on the public equity markets. The pricing of angel finance and venture capital at the origination stage are based in great part on forecasts of valuation at the time of exit. One of the principal valuation techniques involves taking current public market price/earnings multiples and applying them to forecasted earnings at exit. The ex post behavior of the stock market will then determine the timing of exit through the IPO and subsequent offerings, and the valuations associated with those offerings. Thus, when stock market values fall, this can create a chain reaction in which the highly volatile IPO market shuts down, which then may reduce the flow of funds in private angel finance and venture capital equity markets.

It has been found that high realized returns in the venture capital industry tend to lead to increased capital commitments to venture capital funds (Gompers and Lerner 1997, Gompers 1998). Gompers (1998) argued that recently high stock market valuations may have led to an "overheating" of the primary venture capital market. He also found that this increase in the supply of funds flowing into venture capital appears to be associated with a number of different changes in venture capital contracts including: an increase in the share of profits retained by fund general partners; less restrictions in partnership agreements; a shift into later-stage investments; and an increased appetite for international investments.

The ebb and flow of funds into venture capital raises the question of why the primary market for venture capital appears to be myopic and vulnerable to waves of pessimism and optimism. We do not have 
the answer, except to observe that anecdotal evidence suggests that the same myopia seems to exist in primary stock markets, real estate markets, and credit markets. For example, waves of optimism and pessimism may also characterize the pricing of commercial bank loans as credit standards fluctuate over the business cycle.

The venture capital industry is relatively new, but as an intermediated industry, it may be subject to the same types of shocks as affect the commercial banking industry. For instance, some institutional investors might severely contract their new investments in venture capital when they suffer losses in other parts of their portfolios. As indicated earlier, corporate and public pension funds plus endowments together provide more than half of the funding for venture capital limited partnerships. This type of contraction might be similar to the contraction in bank lending that occurred during the credit crunch of the early 1990s (discussed below) that appears to have been caused in part by losses in the banking industry's commercial real estate portfolio. These issues of fluctuations in venture capital funding are extremely interesting and pose difficult challenges for future research.

The overwhelming importance of institutional investors in the U.S. venture capital market is also of interest in and of itself. Prior to the 1980s, U.S. pension funds were effectively barred from any economically significant investment in venture capital because of prudent man rules. However, in 1979 the Department of Labor reinterpreted the Employee Retirement Income Security Act (ERISA) to permit pension fund investment in venture capital provided that it did not endanger the entire portfolio. These and other regulatory changes led to a large increase in the flow of funds into venture capital. As patient investors, pension funds and endowments along with life insurance companies may be ideally suited for investing in venture capital.

Today, vibrant formal venture capital industries are for the most part limited to the U.S. and U.K. The U.S. experience suggests that other countries may wish to consider public policy initiatives that encourage the development of pension funds and their regulatory flexibility to invest in venture capital. ${ }^{30}$ However, the absence of well-developed public equity markets in continental Europe and elsewhere has

\footnotetext{
${ }^{30}$ Many countries, such as Germany, have pay-as-you-go pension systems, and therefore do not have large pension fund industries.
} 
arguably been a significant impediment to the development of venture capital industries. A distinguishing feature of the U.S. financial landscape that makes venture capital investing so attractive is the existence of well-developed public equity markets, particularly markets for small cap stocks such as NASDAQ, which provide the up-side exit for venture capitalists.

\section{The Effects of Shocks to the Banking Industry on Small Business Finance}

In recent years, there have been banking crises involving failures, capital shortfalls, regulatory changes, or other difficulties in a number of countries -- including Japan, Korea, the Scandinavian countries, the U.S., and others -- followed by periods of recessions or reduced economic growth. The transmission mechanism from distress in the banking industry to a decline in macroeconomic performance is not fully known, but arguably it may work in part through a reduction in bank credit to small businesses.

Financial distress in the banking industry can have a short-term effect on lending as banks shrink and reduce their credit risk exposure and try to rebuild equity capital ratios. In addition, bank failures can impose a long-run cost because of the loss of bank-borrower relationships and the information built up through contact over time, making it difficult for some borrowers to continue funding investments that have positive net present values (Slovin, Sushka, and Polonochek 1993). This would most likely affect informationally opaque small businesses that depend on their banks and would have difficulty finding external finance elsewhere. In turn, this reduction in investment may exacerbate regional or macroeconomic difficulties (Bernanke 1983). The regulation and supervision of banks to keep them safe and sound is often justified at least in part on the basis of avoiding systemic crises that might substantially reduce the supply of credit to bank-dependent small businesses.

Monetary Policy Shocks. The "credit channels" of monetary policy transmission are two distinct hypothesized mechanisms through which monetary policy shocks may have disproportionately large effects on small business funding. These mechanisms -- which are based on imperfections in private debt markets -operate alongside the traditional "money view" channel in which monetary policy operates through changing interest rates, which affect the real spending preferences of economic agents.

According to the "bank lending view," the reduction in bank reserves that accompanies a monetary policy tightening results in some banks reducing their supply of loans. This reduction in loan supply forces 
some borrowers to reduce real spending and slow the macroeconomy because alternative means of funding are unavailable or unaffordable, at least in the short term (Bernanke and Blinder 1988). To the extent that the bank lending view holds, it suggests that monetary policy shocks may have disproportionately large effects on bank-dependent relationship borrowers with few alternative sources of funds. This may often apply to small businesses -- at least the half that borrow from banks.

The empirical research generally confirms the two main empirical implications of the bank lending view -- that tight monetary policy reduces the supply of bank loans, and that reduced bank lending slows the macroeconomy (see Kashyap and Stein 1997 for a survey). In addition to the aggregate evidence, the data also confirm that much of the aggregate slowing may be due to adjustments by small businesses. One such finding is that monetary policy appears to have a more potent impact on small banks than large banks (Kashyap and Stein 1995). This is likely to work disproportionately through small firms, since small banks tend to specialize in small business lending. Another finding is that monetary policy shocks appear to affect the growth and investment of small manufacturing firms more than large manufacturers (Gertler and Gilchrist 1994, Bernanke, Gertler, and Gilchrist 1996).

According to the second credit channel mechanism, the "balance sheet channel" or "financial accelerator," the tightening of monetary policy works in part because the associated higher interest rates impair collateral values or otherwise reduce the net worth of certain borrowers, making them less creditworthy and diminishing their ability to obtain funds. Of course, this mechanism can "accelerate" the effects on the macroeconomy of any shock that reduces collateral values or net worth (e.g., oil price increase, real estate market crash), magnifying the effect on the macroeconomy by exacerbating existing informationdriven contracting problems between borrowers and lenders. The balance sheet channel is likely to have a disproportionate effect on the small businesses that have loans from financial institutions, which were found in Table 2 above to pledge collateral on more than $90 \%$ of these loans. This balance sheet channel differs from the bank lending channel in that it implies a reduction in the demand for credit by creditworthy borrowers from all lenders, rather than a reduction in the supply of credit by banks in response to monetary policy tightening. A variety of empirical evidence provides support for this balance sheet channel and its disproportionately large effect on small businesses, including findings linking monetary policy with changes 
in balance sheet strength, and findings linking balance sheet positions with real spending decisions (see Bernanke and Gertler 1995, Bernanke, Gertler, and Gilchrist 1996 for summaries).

The Credit Crunch. The early 1990s in the U.S. has been labeled a credit crunch mostly because of the decline in business lending by U.S. banks. From the end of 1989 to the end of 1992, real domestic commercial and industrial (C\&I) loans held by U.S. banks fell $23.2 \%$, a decline in 1994 dollars from $\$ 596.7$ billion to $\$ 458.2$ billion. Rough estimates based on extrapolation from the STBL suggested that the proportional decline in small business lending (loans to borrowers with bank credit less than $\$ 1$ million) was considerably greater -- an estimated fall of $38.5 \%$ from $\$ 143.7$ billion to $\$ 88.4$ billion in 1994 dollars (Berger, Kashyap, and Scalise 1995). Analysis of other data sources, including the NFIB (Dunkelberg and Dennis 1992) and NSSBF (Avery, Bostic, and Samolyk 1998) also suggested that bank credit was more difficult to obtain for small businesses in the early 1990s than in the late 1980s.

A number of hypotheses of the decline in credit have been tested, including the effects of implementation of the Basle-Accord risk-based capital standards, which generally raised capital requirements against business loans (Haubrich and Wachtel 1993, Berger and Udell 1994, Hancock and Wilcox 1994a, Wagster 1997), regulatory capital actions based on leverage ratios (Berger and Udell 1994, Peek and Rosengren 1994, 1995a, Hancock and Wilcox 1994a, Hancock, Laing, and Wilcox 1995), depletion of bank capital from loan loss experiences of the late 1980s (Peek and Rosengren 1994, 1995a, Hancock and Wilcox 1994a, 1997), greater regulatory scrutiny, including tightened examination criteria, loan loss reserve policies, and formal actions (Bizer 1993, Peek and Rosengren 1995b, Wagster 1997), choices of lower risk profiles by bank managers (Hancock and Wilcox 1993, 1994b), reduced loan demand because of macroeconomic or regional recessions (Bernanke and Lown 1991, Hancock and Wilcox 1993, 1997), or a secular decline in the demand for bank loans because of the growth of alternative sources of credit (Berger and Udell 1994). Although this literature falls short of consensus, the empirical findings generally do not support risk-based capital as a major contributor to the lending slowdown, but do provide some support for most of the other hypotheses.

One study was able to examine the effects of changes in bank capital, loan delinquency rates, and other factors not only on bank lending, but also on the health of small businesses in the same state during the 
credit crunch (Hancock and Wilcox 1998). Hancock and Wilcox found that a $\$ 1$ capital decline at a small bank reduced C\&I lending more than a $\$ 1$ capital decline at a large bank. More important, they found that reductions in capital at small banks during the credit crunch led to statistically and economically significant reductions in the employment, payroll, and number of small businesses in the state. These results highlight the importance of bank lending to small business, and suggest a significant role for capital problems at small banks in the regional and national slowdowns in the early 1990s.

\section{Credit Rationing of Small Business over the Interest Rate and Credit Risk Cycles}

Theories of credit rationing (Stiglitz and Weiss 1981 and others) suggest that moral hazard and adverse selection problems associated with informationally opaque borrowers may be exacerbated when open-market interest rates rise. Lenders may not be able to raise the interest rate to such borrowers in lockstep with rates on government securities for fear of attracting lower quality borrowers or inducing riskshifting behavior. A result is "sticky" loan interest rates and equilibrium credit rationing. It seems likely that if a significant amount of such rationing by banks occurs, it would disproportionately affect the availability of credit to small businesses.

A number of empirical studies found evidence that bank loan rates to business are sticky, providing some support for equilibrium rationing (Slovin and Sushka 1983, King 1986, Sofianos, Wachtel, and Melnik 1990). However, one study used individual loan data from the STBL and found evidence suggesting that this stickiness did not reflect substantial credit rationing. The stickiness was approximately equal for new loans under commitment, which are protected from rationing, and new loans not under commitment. Moreover, the ratio of commitment loans to noncommitment loans did not rise substantially when open-market rates were high, as would be the case if noncommitment borrowers were being rationed (Berger and Udell 1992). Nonetheless, another study using a different data set on the stock of bank loans found that the commitment/noncommitment loan ratio did rise substantially when monetary policy tightened (Morgan 1998).

One explanation for loan rate stickiness other than credit rationing is that banks might provide implicit interest insurance to some of their relationship borrowers. Banks can smooth loan interest rates by providing loans at below-market interest rates for risk-averse relationship borrowers when market rates are 
high and make up for this with above-market rates to the same borrowers when market rates are low or higher prices on other financial products (Fried and Howitt 1980). This may be facilitated by the presence of core deposits with similarly sticky interest rates (Berlin and Mester 1997). As was the case for other benefits from relationship lending described above, the provision of interest rate insurance may be facilitated by the bank having market power over the information acquired through the relationship. The expected future rents to be earned on exclusive access to this information may provide the incentive for the bank to lend at a loss in the short term.

Some empirical evidence supports the notion of interest rate insurance. Some loan interest rates reported on the STBL were below the U.S. Treasury rate of comparable repayment duration when Treasury rates were very high (Berger and Udell 1992). Such loans have negative expected economic returns, and cannot easily be justified without reference to expected profits from elsewhere within the length or breadth of a relationship. Other evidence of loan interest rate stickiness or smoothing on STBL small business loans has also been found, and this stickiness was associated with higher profitability, consistent with the presence of interest rate insurance that represents efficient contracting (Berlin and Mester 1998).

It is similarly possible that banks provide implicit credit risk insurance to some of their relationship borrowers. Banks may continue to provide credit at an expected loss to relationship borrowers that are in temporary distress in the expectation that the short-run loss may be made up in the long run by the value of continuing the relationship. Similar to implicit interest rate insurance, implicit credit risk insurance may be facilitated by the bank having market power over information generated through contact over time in the relationship. Some evidence discussed above -- German "housebanks" lending during periods of distress -is consistent with the presence of credit risk insurance. Similarly, Japanese businesses with longstanding relationships with a main bank have been found to have lower costs of overcoming periods of financial distress (Hoshi, Kashyap, and Sharfstein 1990). Smoothing of rates in response to credit risk shocks was also found in U.S. data, but such smoothing was not clearly associated with higher or lower bank profits, and so may or may not represent an efficient contracting mechanism (Berlin and Mester 1998).

\section{Consolidation of Financial Institutions and the Supply of Small Business Credit}

Mergers and acquisitions (M\&As) of banks and other financial institutions raise a policy concern 
is that the larger organizations created by these M\&As may reduce the availability of credit to small businesses, given the empirical regularity that large banking institutions devote lesser proportions of their assets to small business loans than small institutions (Berger, Kashyap, and Scalise 1995, Keeton 1995, Levonian and Soller 1995, Berger and Udell 1996, Peek and Rosengren 1996, Strahan and Weston 1996). As of the June 1997 CALL, banks with less than $\$ 100$ million in assets had about $9 \%$ of their portfolios invested in small business loans (measured as loans to business borrowers with bank credit less than $\$ 1$ million), whereas banks with over $\$ 10$ billion in assets devoted only about $2 \%$ of their assets to these loans.

This empirical regularity may occur in part because small institutions generally cannot make large business loans due to legal lending limits and problems of diversification. In addition, large institutions may be disinclined to extend relationship-driven small business loans because of Williamson $(1967,1988)$ type organizational diseconomies associated with producing such loans alongside their core business of producing transactions-driven loans and other services for large business customers. That is, it may be too costly to provide relationship-based services -- which often demand intimate knowledge gained over time through contact with the small business, its owner, and its local market -- together with the capital market financial services in which large banks tend to specialize.

The lending quantity data alone do not indicate whether it is relationship loans versus transactions loans that are being issued in lesser proportions by large banking organizations. Nonetheless, some evidence on this point is provided by pricing data. Large banks have been found not only to have much smaller proportions of loans to small borrowers, but they also tend to charge substantially lower average prices to the small borrowers who receive credit from them. Large banks are estimated to charge about 100 basis points less on small businesses loans and require collateral about 25 percent less of the time than small banks, other things equal (Berger and Udell 1996). These data are consistent with the view that large banks tend to issue small business loans to higher-quality transactions-driven credits that can be evaluated based on the same type of analysis of financial ratios as large borrowers, rather than relationship-driven loans to informationally opaque small businesses that tend to have higher interest rates and collateral requirements.

Similar arguments may be made about the effects of greater organizational complexity that may be associated with the banking institutions formed by M\&As. For example, a multibank holding company with 
multiple layers of management that acquires an independent bank in another region of the nation may find it costly to process relationship-based information acquired through contact over time by a local loan officer in a distant local market. However, the data are not as clear regarding complexity as they were regarding size. One study using the STBL found no clear effect of complexity on small business lending (Berger and Udell 1996), whereas studies using CALL data have split on the measured effect of out-of-state ownership of banks (Keeton 1995, Whalen 1995).

A counterargument is that multibank holding companies may be efficient small-business lenders because they can act as internal capital markets that distribute funds to banks with superior local lending opportunities. Supporting this view, it was found that loan growth was less constrained by the bank's financial condition if the bank was part of a multibank holding company than if it was unaffiliated. Instead, what was most important for lending by affiliated banks was the financial condition of their holding company (Houston, James, and Marcus 1997, Houston and James 1998).

The actual effects of M\&As on the supply of small business credit by the consolidating institutions depend not only on the increases in size and organizational complexity of the consolidating institutions, but also on other dynamic changes in their behavior, including possible changes in organizational focus by these institutions. Some studies have analyzed the dynamics of M\&As by comparing small business lending by the consolidating institutions before and after M\&As (Keeton 1996, 1997, Peek and Rosengren 1996, 1998 Strahan and Weston 1996, 1998, Craig and Santos 1997, Kolari and Zardkoohi 1997a,b, Zardkoohi and Kolari 1997, Walraven 1997, Berger, Saunders, Scalise, and Udell forthcoming). The results often differ by type of merger or acquisition, sizes of organizations, econometric technique employed, and number of years after M\&A the lending data were examined. The most common findings are that consolidations of large banking organizations (which involve most of the assets involved in M\&As) tend to reduce small business lending, whereas consolidations involving small organizations tend to increase small business lending, but there are exceptions to these findings.

The total change in the supply of small business credit from M\&As also depends on the reactions of other lenders. For example, if a bank reduces its supply of relationship-driven credit because of diseconomies associated with supplying transactions-driven services, other lenders that are not burdened by 
these diseconomies may react by picking up some or all of these credits. These could occur by other local institutions stepping in or by de novo institutions started by loan officers who have left the consolidating institutions taking some of their relationship-based loan portfolios with them. One study measured the effects of M\&As on the lending of other banks in the same local markets and found evidence suggesting that changes in the supplies of small business credit by these other banks tended to offset much, if not all of the negative effects on small business lending of M\&As (Berger, Saunders, Scalise, and Udell forthcoming). Two other studies found that de novo banks tend to lend more to small businesses as a percentage of assets than other small banks of comparable size, also consistent with the possibility of a positive small business lending reaction to M\&As (Goldberg and White 1998, DeYoung 1998).

Thus, the evidence to date gives some general tendencies of the effects of M\&As on the lending of the banks involved, but the information to date on the reactions of other lenders and the extent to which these reactions run through existing versus de novo banks is quite thin. Moreover, these studies concentrate primarily on the quantities of credit issued, and not the rates charged or other contract terms. The evidence on relationship lending cited above suggests that some borrowers that are dropped by consolidating banks and picked up by other lenders may not only have temporary disruptions of credit, but may also have to pay higher loans rates, pledge more collateral, or be more dependent on trade credit in the short term until their new banking relationships mature.

\section{Conclusions}

Public focus on small business finance derives both from the spectacular success of some recent entrepreneurial firms and from concern that many small businesses with positive net present value projects may not be able to obtain sufficient external finance. Causes for concern include, among others, the recent credit crunches in Asia and the U.S., the lack of well-developed venture capital markets in continental Europe and elsewhere, and the potential impact of financial institution consolidation on the availability of credit to small business everywhere. This paper explores a number of facets of small firm finance, the investors and intermediaries that provide it, and the private equity and debt markets in which they function. We see much of small business finance through a growth cycle paradigm, in which different capital structures are optimal at different points in the cycle, although we emphasize that this paradigm does not fit all small businesses. 
The issues surrounding capital structure for small businesses are generally different than those that are most important for large corporations, and often involve the intertwining of the personal finances of the entrepreneur and other insiders with the finances of the firm. Unlike large firms, small firms typically have a substantial amount of their funding provided by insiders -- the entrepreneur, other members of the start-up team, family, and friends. In addition, small businesses generally receive their external funding in private equity and debt markets, rather than public markets. Part of the capital structure decision for small firms is whether and when to enter public capital markets via an IPO, although the vast majority of firms never reach this point in the financial growth cycle. Even the distinction between insider finance and external finance in small business is not always completely clear, since insiders often give personal guarantees or pledge personal collateral against external debt provided by financial institutions. The intermediaries in private markets also evaluate the personal finances of the inside owners -- including assets that are not invested in the firm -- so these personal assets also have a bearing on the capital structure of the firm. Finally, the vast majority of small businesses are owner-managed, which alleviates agency conflicts between owners and managers that affect capital structure choices in large corporations. However, owner management may introduce other factors into capital structure decisions of small firms, such as the owner/manager's level of risk aversion, or his/her incentive to issue external debt rather than external equity in order to keep ownership and control of the firm.

We argue that the degree of informational opacity is a key feature that drives the financial growth cycle and that distinguishes small business finance from large business finance. Deviations from the Modigliani and Miller (1958) assumption that agents can write contracts based on full information have been used to explain capital structure in corporate finance for the last 40 years, and these informational imperfections are arguably much more applicable to small business finance. Early in the growth cycle, small businesses typically do not have audited financial statements, do not have many business assets that can be easily evaluated or pledged as collateral, and have little repayment history or record of profitability upon which external suppliers of funds can rely. For such firms, outsiders often put considerable weight on the creditworthiness and reputation of the entrepreneur, who may have a longer credit history, more pledgeable assets, and personal data that are easier to evaluate than the records of the firm. Even after some experience, 
small businesses may remain opaque relative to large firms because their activities are not publicly visible, and because they do not issue traded securities which are continuously priced in public equity and debt markets.

Theory offers some suggestions on the effects of informational opacity on capital structure. The pecking order suggests that informational opacity will favor first using insider funds generated within the firm or from the entrepreneur and other insiders that have superior information about the firm. The modern information-based theory of security design predicts that the mix among external equity and debt sources will be affected by three dimensions of informational opacity -- costly state verification, adverse selection, and moral hazard. Costly state verification and adverse selection problems tend to favor external debt contracts, whereas moral hazard problems tend to favor external equity contracts. Differences in the relative severity of these information problems may help explain why certain types of small businesses obtain external equity from angels and venture capitalists, whereas other types tend to rely more on external debt from banks, finance companies, and trade creditors. Of course informational opacity also may keep firms from obtaining significant amounts of external funding at all. Only about half of small businesses have loans outstanding from financial institutions and even fewer tap external equity markets, although to some extent the lack of external finance may reflect the choice of the entrepreneur.

The relative shares among private equity and debt suppliers also depends on their abilities to resolve information problems. Intermediaries engage in screening, contracting, and monitoring activities to address information problems. They offer highly structured, complex contracts to small businesses, in contrast to the contracts employed in public markets which are more often generic in nature. Nonetheless, there are important differences among the intermediaries in the way they address the information problems of small businesses. For example, venture capitalists may participate in strategic planning and operational decision making, whereas banks use collateral, commitments, restrictive covenants, and short maturities to sort firm types and restrain firms from engaging in risk-shifting behavior. Banks also often form long-term relationships through continuous contact with the firm and entrepreneur in the provision of multiple financial services. Banks then use the information gathered over the course of relationships to help make additional contracting and monitoring decisions, although the exercise of market power over this information can cause 
other problems. Trade creditors -- who provide almost as much credit to small business as banks -- may have superior information about the firm, may be able to solve incentive problems by threatening to withhold future supplies, may have advantages in repossessing and selling the supplied goods, and may be able to provide extra funds during crisis periods in the banking industry. The choice among these and other sources of funds depends in part on which types of information problems the firm has, and which sources are best suited to resolve these problems.

We identify the extent to which U.S. small business is financed by four different sources of equity and nine different sources of debt, and show how the capital structure changes with the size and age of the firm. This analysis confirms some of the conventional wisdom and also offers some surprises. The three largest sources of funding are the principal owner, commercial banks, and trade creditors, which together account for over $70 \%$ of total small business finance, consistent with conventional wisdom. However, credit card debt appears to be surprisingly unimportant, providing less than $1 \%$ of small business finance. In addition, financial institution debt appears to be an important source of funding to very young firms, contrary to the conventional wisdom that such funding would typically not be available to small businesses until they had acquired substantial tangible business assets that might be pledged as collateral. The data also provide a solution to this puzzle. The evidence suggests that financial institution debt is often based on recourse against the personal wealth of the entrepreneur through guarantees or pledges of personal collateral.

We use this taxonomy of sources of finance as a backdrop against which we analyze the extant research on a wide variety of sources of funding to small business, including insider seed finance, angel finance, venture capital, commercial bank and finance company loans, trade credit, government sponsored finance, and others. We also examine the nature of specific screening, contracting, and monitoring features associated with the provision of external equity and debt including among others, collateral, guarantees, commitments, covenants, maturity, relationship lending, interest rates, and venture capital pricing and control. In addition, the nature and importance of the financial intermediaries and markets that provide external equity and debt to small business are analyzed. We emphasize that the modern theory of financial intermediation is based largely on resolving information problems, which are most acute in small business finance. 
We also emphasize many ways in which the different sources of small business finance are interconnected through reference to the growth cycle paradigm. The extant research is quite fragmented into separate literatures on such issues as financial contracting, venture capital, relationship lending, the impact of credit crunches, the impact of banking industry consolidation, the IPO market, etc. Part of our objective is to bring these literatures together in one place. We try to make connections among these literatures in order to demonstrate how these various types of small firm finance and markets are related in ways that help explain financial security design and capital market structure as it applies to small business.

As well, we analyze the vulnerability of small firm finance to the macroeconomic environment. This involves a variety of issues including: the fragility of private equity markets and their strong reactions to current events in public equity markets; the effects of monetary policy shifts; bank credit crunches caused by regulatory changes, macroeconomic conditions, or capital problems in the banking industry; credit rationing over the interest rate and credit risk cycles; and the continuing effects of the consolidation of financial institutions. In great part, the vulnerability of small businesses to these changes stems from the informational opacity of small firms and imperfections in the screening, contracting, and monitoring procedures of intermediaries in addressing information problems. The legal and informational infrastructures play key roles. Well-defined bankruptcy laws that clearly establish priority, clarify the process of bankruptcy, and reduce the uncertainty of outcome are critical. Information-rich environments characterized by well-defined accounting standards, sophisticated accounting expertise, and well-developed mechanisms for information sharing are also critical. Current research on contracting across countries suggests that these differences in environment can have significant effects on contract structure, contracting costs, and the availability of external finance to small business.

While much research has begun on the topic of small business finance, even more remains to be done. Our analysis of the financial growth cycle and the interconnectedness of small firm finance suggests that some of the most exciting areas for future research may involve investigating how sources of small firm finance may change over the business cycle, in reaction to changes in government policy, during times of distress in private or public markets, and as information processing technology continues to improve. Moreover, it is important to determine the effects of the availability and cost of small business finance on 
the formation of new firms, their ability to engage in risky or opaque activities, and their effects on employment, real output, and economic growth. The availability of new data resources described and employed here should prove very useful in pursuing these and other research agendas on small business finance. 


\section{References}

Acs, Z., and F.A. Tarpley, Jr., The angel capital electronic network (ACE-Net), Journal of Banking and Finance 22.

Adler, B.E., 1993, An equity agency solution to the bankruptcy priority puzzle, Journal of Legal Studies 22, 7398.

Admati, A.R., and P. Pfleiderer, 1994, Robust financial contracting and the role of venture capitalists, Journal of Finance 49, 371-402.

Allen, L., A. Saunders, and G.F. Udell, 1991, The pricing of retail deposits: Concentration and information. Journal of Financial Intermediation 1, 335-361.

Alon, B., and P.A. Gompers, 1997, Myth or reality? The long-run underperformance of initial public offerings: Evidence from venture and nonventure capital backed companies, Journal of Finance 52, 1791-1821.

Amit, R., L., Glosten and E. Muller, 1990, Entrepreneurial ability, venture investments, and risk sharing, Management Science 36, 1232-1245.

Ang, J.S., 1992, On the theory of finance for privately held firms, Journal of Small Business Finance 1, 185-203.

Ang, J.S., J.W. Lin, and F. Tyler, 1995, Evidence on the lack of separation between business and personal risks among small businesses, Journal of Small Business Finance 4, 197-210.

Angelini, P., R. Di Salvo, and G. Ferri, 1998, Availability and cost for small businesses: Customer relationships and credit cooperatives, Journal of Banking and Finance 22.

Avery, R.B. and A.N. Berger, 1991, Loan commitments and bank risk exposure, Journal of Banking and Finance $15,173-192$ (a).

Avery, R.B. and A.N. Berger, 1991, Risk-based capital and deposit insurance reform, Journal of Banking and Finance 15,847-874 (b).

Avery, R., R.W. Bostic, and K.A. Samolyk, 1998, The evolution of small business finance: The role of personal wealth, Journal of Banking and Finance 22.

Barry, C.B., 1994, New directions in research on venture capital finance, Financial Management 23, 3-15.

Barry, C.B., C.J. Muscarella, J.W. Peavy III, and M.R. Vetsuypens, 1990, The role of venture capital in the creation of public companies: evidence from the going public process, Journal of Financial Economics $27,447-471$.

Benveniste, L.M., W.Y. Busaba, and W.J. Wilhelm, 1996, Price stabilization as a bonding mechanism on new equity issues, Journal of Financial Economics 42, 223-255.

Benveniste, L.M., S.E. Erdal, and W.J. Wilhelm, Jr., Who benefits from secondary market price stabilization of IPOs? Journal of Banking and Finance 22.

Benveniste, L.M. and P. A. Spindt, 1989, How investment bankers determine the offer price and allocation of new issues, Journal of Financial Economics 24, 343-362. 
Bergemann, D., and U. Hege, 1998, Dynamic venture capital financing and learning, Journal of Banking and Finance 22.

Berger, A.N., A.K Kashyap, and J.M. Scalise, 1995, The transformation of the U.S. banking industry: What a long, strange trip it's been, Brookings Papers on Economic Activity (2:1995), 55-218.

Berger, A.N., A. Saunders, J.M. Scalise, and G.F. Udell, forthcoming, The effects of bank mergers and acquisitions on small business lending, Journal of Financial Economics.

Berger, A. N. and G.F. Udell, 1990, Collateral, loan quality, and bank risk, Journal of Monetary Economics 25, $21-42$.

Berger, A. N. and G.F. Udell, 1992. Some evidence on the empirical significance of credit rationing, Journal of Political Economy 100, 1047-1077.

Berger, A.N. and G. F. Udell, 1993, Securitization, Risk, and the Liquidity Problem in Banking, edited by M. Klausner and L.J. White, Structural Change in Banking, Homewood, IL, Irwin Publishing, 227-91.

Berger, A.N., and G.F. Udell, 1994, Did risk-based capital allocate bank credit and cause a 'credit crunch' in the U.S.?," Journal of Money, Credit and Banking 26, 585-628.

Berger, A.N. and G.F. Udell, 1995, Relationship lending and lines of credit in small firm finance, Journal of Business 68, 351-382.

Berger, A. N. and G. F. Udell, 1996, Universal banking and the future of small business lending, edited by A. Saunders and I. Walter, Financial System Design: The case for universal banking, Burr Ridge, IL, Irwin Publishing, 559-627.

Berkovitch, E. and S.I. Greenbaum, 1991, The loan commitment as an optimal financing contract, Journal of Financial and Quantitative Analysis 26, 83-95.

Berlin, M. and J. Loeys, 1988, Bond covenants and delegated monitoring, Journal of Finance, 43, 397-412.

Berlin, M. and L.J. Mester, 1993, Debt covenants and renegotiation, Journal of Financial Intermediation 2, $95-$ 133.

Berlin, M. and L.J. Mester, 1997, Why is the banking sector shrinking? Core deposits and relationship lending, Working Paper \#96-18R, Federal Reserve Bank of Philadelphia.

Berlin, M. and L.J. Mester, 1998, On the profitability and cost of relationship lending, Journal of Banking and Finance 22.

Bernanke, B. 1983, Non-monetary effects of the financial crisis in the propagation of the great depression, American Economic Review 73, 257-76.

Bernanke, B.S., and A. Blinder, 1988, Credit, money, and aggregate demand, American Economic Review 78, 435-39.

Bernanke, B.S., and M. Gertler, 1995, Inside the black box: The credit channel of monetary policy transmission, Journal of Economic Perspectives 9, 27-48. 


$$
\mathrm{R}-3
$$

Bernanke, B., M. Gertler, and S. Gilchrist, 1996, The financial accelerator, and the flight to quality, Review of Economics and Statistics 78, 1-15.

Bernanke, B.S., and C.S. Lown, 1991, The credit crunch, Brookings Papers on Economics Activity, 1991:2, 20548.

Besanko, D. and A.V. Thakor, 1987, Collateral and rationing: Sorting equilibria in monopolistic and competitive markets, International Economic Review 28, 671-689 (a).

Besanko, D. and A.V. Thakor, 1987, Competitive equilibrium in the credit market under asymmetric information, Journal of Economic Theory 42, 167-182 (b).

Bester, H., 1985, Screening vs. rationing in credit markets with imperfect information, American Economic Review 75, 850-855.

Biais, B., and C. Gollier, 1997, Trade credit and credit rationing, Review of Financial Studies 10, 903-937.

Billett, M.T., M.J. Flannery and J.A. Garfinkel, 1995, The effect of lender identity on a borrowing firm's equity return, Journal of Finance 50, 699-718.

Bizer, D.S., 1993, "Regulatory discretion and the credit crunch," working paper, U.S. Securities and Exchange Commission, Washington DC (April).

Blackwell, D., and D.B. Winters, 1997, Banking relationships and the effect of monitoring on loan pricing, Journal of Financial Research 20, 275-89.

Board of Governors of the Federal Reserve System, 1988, Senior loan officer opinion survey on bank lending practices (May).

Boot, A.W.A., and A.V. Thakor, 1994, Moral hazard and secured lending in an infinitely repeated credit market game, International Economic Review, 35, 899-920.

Boot, A.W.A., A.V. Thakor, and G. Udell, 1987, Competition, risk neutrality and loan commitments, Journal of Banking and Finance 11, 449-471.

Boot, A.W.A., A.V. Thakor and G.F. Udell, 1991, Secured lending and default risk: Equilibrium analysis and policy implications and empirical results, The Economic Journal 101, 458-472.

Booth, J.R. 1992, Contract costs, bank loans, and the cross-monitoring hypothesis, Journal of Financial Economics 31, 2-41.

Booth, J.R., and L. Chua, 1996, Loan collateral decisions and corporate borrowing costs, Arizona State University Working Paper.

Boyd, J. and E. C. Prescott, 1986, Financial intermediary-coalitions, Journal of Economic Theory 38, 211-232.

Bostic, R.W., and G.B. Canner, 1998, New information on small business and small farm lending, Federal Reserve Bulletin, 84 .

Brady, T.F., W.B. English, and W.R. Nelson, 1998, Recent changes to the Federal Reserves's Survey of Terms 


$$
\mathrm{R}-4
$$

of Business Lending, Federal Reserve Bulletin, 84.

Brewer, E. and H. Genay, 1994, Funding small businesses through the SBIC program, Federal Reserve Bank of Chicago Economic Perspectives 18, 22-34.

Brewer, E., H. Genay, W.E. Jackson, P.R. Worthington, 1997, The security issue decision: Evidence from small business investment companies, Federal Reserve Bank of Chicago working paper.

Calomiris, C., C. Himmelberg, and P. Wachtel, 1995, Commercial paper, corporate finance and the business cycle: A microeconomic perspective, Carnegie-Rochester Series on Public Policy 42, 203-50.

Carey, M., 1996, Financial covenants, private debt, and financial intermediation, Board of Governors of the Federal Reserve Working Paper.

Carey, M., M. Post, and S.A. Sharpe, forthcoming, Does corporate lending by banks and finance companies differ? Evidence on specialization in private debt contracting, Journal of Finance.

Carey, M., S. Prowse, J. Rea, and G. F. Udell, 1993, The economics of private placements: A new look, Financial Markets, Institutions and Instruments 2.

Cavalluzzo, K. and L. Cavalluzzo, forthcoming, Market structure and discrimination: The case of small business, Journal of Money, Credit and Banking.

Chan, Y.-S. and G. Kanatas, 1985, Asymmetric valuation and the role of collateral in loan agreements, Journal of Money, Credit and Banking 17, 85-95.

Chan, Y.-S., D. Siegal and A.V. Thakor, 1990, Learning, corporate control and performance requirements in venture capital contracts, International Economic Review 31, 365-381.

Cole, R.A., 1997, Availability of credit to small and minority-owned businesses: Evidence from the 1993 National Survey of Small Business Finances, Federal Reserve Board working paper.

Cole, R.A., 1998, The importance of relationships to the availability of credit, Journal of Banking and Finance 22.

Cook, L., 1997, Trade finance, bank finance, and capital market imperfections, Harvard University working paper.

Cooper, I. and W. Carleton, 1979, Dynamics of borrower-lender interaction: partitioning the final payoff in venture capital finance, Journal of Finance 34, 517-529.

Chowdhry, B. and V. Nanda, 1996, Stabilization, syndication and pricing of IPOs, Journal of Financial and Quantitative Analysis 31, 25-42.

Cornelli, F. and O. Yosha, 1997, Stage financing and the role of convertible debt, Institute of Financing and Accounting, London Business School, WP 253-1997.

Covitz, D.M., 1997, The role of public reputation in small firm finance, working paper, Board of Governors of the Federal Reserve System. 


\section{$\mathrm{R}-5$}

Craig, B.R. and J.C.d. Santos, 1997, Banking consolidation, Impact on small business lending, Working Paper, Federal Reserve Bank of Cleveland.

Cressy, R. and O. Toivanen, 1997, Is there adverse selection in the credit market? University of Warwick working paper.

Detragiache, E, P.G. Garella, and L. Guiso, 1997, Multiple versus single banking relationships, Banca D'Italia Working Paper.

DeYoung, R., 1998, Comment on Goldberg and White, Journal of Banking and Finance 22.

Diamond, D.W., 1984, Financial intermediation and delegated monitoring, Review of Economic Studies 51, 393-414.

Diamond, D.W.,1991, Monitoring and reputation: The choice between bank loans and directly placed debt, Journal of Political Economy 99, 688-721.

Diamond, D.W., 1993, Seniority and the maturity of debt contracts, Journal of Financial Economics 33, 341-68.

Duca, J.V., 1998, Comment on Cole, Journal of Banking and Finance 22.

Dunkelberg, W., 1998, Credit, banks and small business in America, Journal of Banking and Finance 22.

Dunkelberg, W.C., and W.J. Dennis, Jr., 1992, The small business "credit crunch," The NFIB Foundation, Washington, DC.

Eisenbeis, R.A., 1998, Comment on Hancock and Wilcox, Journal of Banking and Finance 22.

Elliehausen, G.E., and J.D. Wolken, 1993, The demand for trade credit: An investigation of motives for trade credit by small businesses, Staff study 165, Board of Governors of the Federal Reserve System, Washington, DC.

Elsas, R., and J.P. Krahnen, 1997, Is relationship lending special? Evidence from credit-file data in Germany, Working Paper, Johann Wolfgang Goethe-University Frankfurt.

Fenn, G.W., and N. Liang, 1998, New resources and new ideas: Private equity for small business, Journal of Banking and Finance 22.

Fenn, G.W., N. Liang, and S. Prowse, 1997, The private equity market: An overview, Financial Markets, Institutions, and Instruments 6, 1-9.

Ferris, J.S., 1981, A transactions theory of trade credit use, Quarterly Journal of Economics 96, 243-270.

Flannery, M.J., 1998, Comment on Benveniste, Erdal, and Wilhelm, Jr., Journal of Banking and Finance 22.

Fluck, Z., D. Holtz-Eakin, and H.S. Rosen, 1997, Where does the money come from? The financing of small entrepreneurial enterprises, New York University working paper.

Freear, J., J.E. Sohl, and W.E. Wetzel, Jr., 1994, The private investor market for venture capital, The Financier, 1, 7-19. 
Fried, V.H. and R.D. Hisrich, 1994, Towards a model of venture investment decision making, Financial Management 23, 28-37.

Fried, J., and P. Howitt, 1980, Credit rationing and implicit contract theory, Journal of Money, Credit and Banking 12, $471-486$.

Garmaise, M., 1997, Informed investors and the financing of entrepreneurial projects, Stanford University working paper.

Gertler, M, and S. Gilchrist, 1994, Monetary policy, business cycles, and the behavior of small manufacturing firms, Quarterly Journal of Economics 109, 309-40.

Gifford, S., 1994, On the relationship between venture capital the entrepreneur, Boston University Unpublished Manuscript.

Goldberg, L.G. and L.J. White, 1998, De novo banks and lending to small businesses, Journal of Banking and Finance 22.

Gompers, P.A., 1993, Incentives, screening and venture capital: A role for convertible debt, University of Chicago Unpublished Manuscript.

Gompers, P.A., 1995, Optimal investment, monitoring, and the staging of venture capital, Journal of Finance $50,1461-1489$.

Gompers, P.A., 1996, Grandstanding in the venture capital industry, Journal of Financial Economics 42, 133-156.

Gompers, P.A., 1998, Venture capital growing pains: Should the market diet? Journal of Banking and Finance 22.

Gompers, P.A., and J. Lerner, 1994a, An analysis of compensation in the U.S. venture capital partnership, University of Chicago and Harvard University working paper.

Gompers, P.A., and J. Lerner, 1994b, Venture capital distributions: Inside information, downward sloping demand curves, and corporate control, University of Chicago and Harvard University working paper.

Gompers, P.A., and J. Lerner, 1996, The use of covenants: an empirical analysis of venture partnership agreements, Journal of Law and Economics 39, 463-498.

Gompers, P.A., and J. Lerner, 1997, Money chasing deals? The impact of fund inflows on private equity valuations, Harvard University working paper.

Gorman, M. and W.A. Sahlman, 1989, What do venture capitalists do? Journal of Business Venturing 4, $213-$ 248.

Gorton, G., and J. Kahn, 1997, The design of bank loan contracts, collateral, and renegotiation, University of Pennsylvania Working Paper.

Greenbaum, S.I., G. Kanatas and I. Venezia, 1989, Equilibrium loan pricing under the bank-client relationship, Journal of Banking and Finance 13, 221-35. 
Gupta, A.K. and J.J. Sapienza, 1992, Determinants of capital firms' preferences regarding the industry diversity and geographic scope of their investments, Journal of Business Venturing 7, 347-362.

Hadlock, C., and C.M. James, 1997, Bank lending and the menu of financing options, University of Florida working paper.

Hancock, D., A. Laing, and J.A. Wilcox, 1995, Bank balance sheet shocks and aggregate shocks: Their dynamic effects on bank capital and lending, Journal of Banking and Finance, 19, 661-77.

Hancock, D., and J.A. Wilcox, 1993, Has there been a 'capital crunch' in banking? The effects on bank lending of real estate market conditions and bank capital shortfalls, Journal of Housing Economics, 3, 31-50.

Hancock, D., and J.A. Wilcox, 1994, Bank capital and the credit crunch: The roles of risk-weighted and unweighted capital regulations, AREUEA, 22, 59-94 (a).

Hancock, D., and J.A. Wilcox, 1994, Bank capital, loan delinquencies, and real estate lending, Journal of Housing Economics, 4, 121-46 (b).

Hancock, D. and J.A. Wilcox, 1997, Bank capital, nonbank finance, and real estate activity, Journal of Housing Research, 8, 75-105.

Hancock, D. and J.A. Wilcox, 1998, The 'Credit crunch' and the availability of credit to small business, Journal of Banking and Finance 22.

Harhoff, D. and T. Korting, 1997, Lending relationships in Germany: empirical results from survey data, working paper.

Haubrich, J., and P. Wachtel, 1993, Capital requirements and shifts in commercial bank portfolios, Federal Reserve Bank of Cleveland Economic Review, 29 (Quarter 3), 2-15.

Hellman, T., 1993, Financial structure and control in venture capital, Stanford University working paper.

Hempel, G., A. Coleman, and D. Simonson, 1986, Bank Management, New York, John Wiley \& Sons.

Hester, D, 1979, Customer relationships and terms of loans: Evidence from a pilot survey, Journal of Money, Credit and Banking 11, 349-357.

Ho, R., 1997, Credit-card use to finance small business is soaring, says survey of small firms, Wall Street Journal, B2, Sept. 25.

Hoshi, T., A.K Kashyap, and D. Sharfstein, 1990, The role of banks in reducing the costs of financial distress in Japan, Journal of Financial Economics 27, 67-88.

Houston, J.F. and C.M. James, 1996, Bank information monopolies and the mix of private and public debt choices, Journal of Finance 51, 1863-1889.

Houston, J.F. and C.M. James, 1998, Do bank internal capital markets promote lending?, Journal of Banking and Finance 22.

Houston, J.F., C.M. James, and D. Marcus, 1997, Capital market frictions and the role of internal capital 


\section{$\mathrm{R}-8$}

markets in banking, forthcoming Journal of Financial Economics 46, 135-164.

Houston, J.F. and S. Venkataraman, 1994, Information revelation, lock-in, and bank loan commitments, Journal of Financial Intermediation 3, 355-78.

James, C. 1987, Some evidence on the uniqueness of bank loans, Journal of Financial Economics 19, 217-235.

Jayaratne, J. and P.E. Strahan, 1996, The finance-growth nexus: Evidence from bank branch deregulation, Quarterly Journal of Economics 111, 639-670.

John, K., A.W. Lynch, and M. Puri, 1997, Collateral and perquisite consumption: Theory and evidence, New York University working paper.

John, K. and E. Ofek, 1995, Asset sales and increase in focus, Journal of Financial Economics 37, 105-126.

Kashyap, A.K, 1998, Comment on Angelini, Di Salvo and Ferri, Journal of Banking and Finance 22.

Kashyap, A.K, and J.C. Stein, 1995, Monetary policy and bank lending, Carnegie-Rochester Series on Public Policy 42, 151-95.

Kashyap, A.K and J.C. Stein, 1997, The role of banks in monetary policy: A survey with implications for the European Monetary Union, Economic Perspectives, Federal Reserve Bank of Chicago, September/October, 3-18.

Kanatas, G., 1987, Commercial paper, bank reserve requirements, and the informational role of loan commitments, Journal of Banking and Finance 11, 425-448.

Karsai, J., M. Wright, Z. Dudzinski, and J. Morovic, 1997, Emerging venture capital markets: Evidence from Hungary, Poland and Slovakia, University of Nottingham working paper.

Keeton, W. R., 1995, Multi-office bank lending to small businesses: Some new evidence, Federal Reserve Bank of Kansas City Economic Review 80 (2), 45-57.

Keeton, W.R., 1996, Do bank mergers reduce lending to businesses and farmers? New evidence from tenth district states, Federal Reserve Bank of Kansas City Economic Review 81 (3), 63-75.

Keeton, W.R., 1997, The effects of mergers on farm and business lending at small banks: New evidence from tenth district states, Working Paper, Federal Reserve Bank of Kansas City.

King, S.R., 1986, Monetary transmission: Through bank loans or bank liabilities?, Journal of Money, Credit and Banking 8, 290-303.

Klapper, L., 1998, Short-term collateralization: Theory and evidence, New York University working paper.

Kolari, J., and A. Zardkoohi, 1997, The impact of structural change in the banking industry on small business lending, Report to the Small Business Administration (a).

Kolari, J., and A. Zardkoohi, 1997, Bank acquisitions and small business lending, working paper, Texas A\&M University (b). 


\section{$\mathrm{R}-9$}

Koppenhaver, G.D., 1989, The effects of regulation on bank participation in the guarantee market, edited by G. Kaufman, Research in Financial Services: Private and Public Policy, JAI Press, Inc., Greenwich, Conn., 165-180.

Kwan, S.H. and W.T. Carleton, 1993, The structure and pricing of private placement corporate loans, University of Arizona working paper.

Leeth, J.D., and J.A. Scott, 1989, The incidence of secured debt: Evidence from the small business community, Journal of Financial and Quantitative Analysis 24, 379-94.

Lerner, J., 1994, The syndication of venture capital investments, Financial Management, 16-27 (a).

Lerner, J., 1994, Venture capitalists and the decision to go public, Journal of Financial Economics, 293-316 (b).

Lerner, J., 1995, Venture capitalists and the oversight of private firms, Journal of Finance 50, 301-18.

Lerner, J, 1998, “Angel” financing and public policy: An overview, Journal of Banking and Finance 22 (a).

Lerner, J., 1988, Comment on Bergemann and Hege, Journal of Banking and Finance 22 (b).

Levinson, A.R., and K.L. Willard, 1997, Do firms get the financing they want? Measuring credit constraints among small businesses in the U.S., working paper, Milken Institute.

Levonian, M. and J. Soller, 1995, Small banks, small loans, small business, Federal Reserve Bank of San Francisco Working Paper.

Lummer, S.L. and J.J. McConnell, 1989, Further evidence on the bank lending process and the capital market response to bank loan agreements, Journal of Financial Economics 25, 99-122.

Majewski, S.E., 1997, Using strategic alliance formation as a financing mechanism in the biotechnology industry, University of California, Berkeley working paper.

Mann, R.J., 1998, Comment on Avery, Bostic and Samolyk, Journal of Banking and Finance 22.

Marx, L.M., 1993, Negotiation and renegotiation of venture capital contracts, Northwestern University working paper.

Megginson, W.L. and K.A. Weiss, 1991, Venture capitalist certification in initial public offerings, Journal of Finance 46, 979-903.

Melnik, A., and S.E. Plaut, 1986, Loan commitment contracts, terms of lending, and credit allocation, Journal of Finance 41, 425-35.

Meyer, L.H., 1998, The present and future roles of banks in small business finance, Journal of Banking and Finance 22.

Mian, S., and C. Smith, 1992, Accounts receivable management policy: Theory and evidence, Journal of Finance 47, 169-200.

Mikkelson, W., and M. Partch, 1986, Valuation effects of securities offerings and the issuance process, Journal 


$$
\mathrm{R}-10
$$

of Financial Economics 15, 31-60.

Modigliani, F., and M. Miller, 1958, The cost of capital, corporation finance, and the theory of investment, American Economic Review 48, 261-97.

Morgan, D.P., 1994, Bank credit commitments, credit rationing, and monetary policy, Journal of Money, Credit, and Banking 26, 87-101.

Morgan, D.P., 1995, Bank monitoring mitigates agency problems: New evidence using financial commitments in bank loan commitments, Paine Webber working paper PW-95-12, Columbia University.

Morgan, D.P., 1998, The credit effects of monetary policy: Evidence using loan commitments, Journal of Money, Credit, and Banking 30, 102-18.

Morsman, E. Jr., 1986, Commercial loan structuring, Journal of Commercial Bank Lending 68, 2-20.

Myers, S., 1977, Determinants of corporate borrowing, Journal of Financial Economics 5, 147-175.

Myers, S., 1984, Presidential address: The capital structure puzzle, Journal of Finance 39, 575-92.

Myers, S.C., and N.C. Majluf, 1984, Corporate financing and investment decisions when firms have information that investors do not have, Journal of Financial Economics, 13, 187-221.

Nachman, D.C., and T.H. Noe, 1994, Optimal design of securities under asymmetric information, Review of Financial Studies 7, 1-44.

Nakamura, L.I. 1993, Commercial bank information: Implications for the structure of banking, in M. Klausner and L.J. White, editors, Structural change in banking, Homewood, IL: Irwin, 131-160.

Ongena, S., and D. Smith, 1997, Empirical evidence on the duration of banking relationships, working paper, Norwegian School of Management.

Nilsen, J.H., 1994, Trade credit and the bank lending channel of monetary policy, working paper, Princeton University.

Norton, E., and B.H. Tenenbaum, 1993, Specialization versus diversification as a venture capital investment strategy, Journal of Business Venturing 8, 431-442.

Orgler, Y., 1970, A credit scoring model for commercial loans, Journal of Money, Credit and Banking 2, 435445.

Padilla, A.J., and M. Pagano, 1997, Endogenous communication among lenders and entrepreneurial incentives, Review of Financial Studies 10, 205-236.

Pagano, M., 1998, Comment on Berlin and Mester and Houston and James, Journal of Banking and Finance 22.

Peek, J., and E.S. Rosengren, 1994, Bank real estate lending and the New England capital crunch, AREUEA 22, 33-58.

Peek, J., and E.S. Rosengren, 1995, The capital crunch: Neither a borrower nor a lender be, Journal of Money, 
Credit and Banking, 27, 625-38 (a).

Peek, J., and E.S. Rosengren, 1995, Bank regulation and the credit crunch, Journal of Banking and Finance, 19, 679-92 (b).

Peek, J. and E.S. Rosengren, 1996, Small business credit availability: How important is size of lender? edited by $A$. Saunders and I. Walter, Financial system design: The case for universal banking, Burr Ridge, IL, Irwin Publishing.

Peek, J. and E.S. Rosengren, 1998, Bank consolidation and small business lending: It's not just bank size that matters, Journal of Banking and Finance 22.

Petersen, M.A. and R.G. Rajan, 1994, The benefits of firm-creditor relationships: Evidence from small business data, Journal of Finance 49, 3-37.

Petersen, M.A. and R.G. Rajan, 1995, The effect of credit market competition on lending relationships, Quarterly Journal of Economics 110, 407-443.

Pratt, E.S. and J.K. Morris, 1987, Pratt's guide to venture capital sources (Venture Economics, Inc., Wellesley).

Prowse, S., 1998, Angel investors and the market for angel investments, Journal of Banking and Finance 22.

Rajan, R.G., 1992, Insiders and outsiders: The choice between informed and arm's-length debt, Journal of Finance 47, 1367-99.

Rajan, R.G., and A. Winton, 1995, Covenants and collateral as incentives to monitor, Journal of Finance 50, 1113-1146.

Ramakrishnan, S. and A.V. Thakor, 1984, Information reliability and a theory of financial intermediation, Review of Economic Studies 51, 415-432.

Ravid, S.A., 1996, Debt maturity -- A survey, Financial Markets, Institutions and Instruments 5, no. 3, 1-68.

Rock, K., 1986, Why new issues are underpriced, Journal of Financial Economics 15, 187-212.

Rosen, H.S., 1998, The future of entrepreneurial finance, Journal of Banking and Finance 22.

Rosen, R.J., 1998, Comment on Peek and Rosengren and Strahan and Weston, Journal of Banking and Finance 22.

Ruhnka, J.C. and J.E. Young, 1991, Some hypotheses about risk in venture capital investing, Journal of Business Venturing 6, 115-133.

Sahlman, W.A., 1988, Aspects of financial contracting in venture capital investment, Journal of Applied Corporate Finance 27, 23-36.

Sahlman, W.A., 1990, The structure and governance of venture-capital organizations, Journal of Financial Economics 27, 473-521.

Scott, J.A. and T.C. Smith, 1986, The effect of the bankruptcy reform act of 1978 on small business loan 
pricing, Journal of Financial Economics 16,119-140.

Sharpe, S.A., 1990, Asymmetric information, bank lending, and implicit contracts: A stylized model of customer relationships, Journal of Finance 45,1069-87.

Slovin, M.B. and M.E. Sushka, 1983, A model of the commercial loan rate, Journal of Finance 38, 1583-96.

Slovin, M.B., M.E. Sushka, and J.A. Polonochek, 1993, The value of bank durability: Borrowers as bank stakeholders, Journal of Finance 48, 247-66.

Smith, C., and J. Warner, 1979, Bankruptcy, secured debt, and optimal capital structure: Comment, Journal of Finance 34, 247-51.

Smith, J.K., 1987, Trade credit and information asymmetries, Journal of Finance 42, 863-72.

Sofianos, G., P. Wachtel, and A. Melnik, 1990, Loan commitments and monetary policy, Journal of Banking and Finance 14, 677-89.

Stiglitz, J., and A. Weiss, 1981, Credit rationing in markets with imperfect information, American Economic Review 71, 93-410.

Stiglitz, J., and A. Weiss, 1986, Credit rationing and collateral, edited by J. Edwards, J. Franks, C. Mayer and S. Schaefer, eds., Recent Developments in Corporate Finance New York: Cambridge University Press, 101-35.

Storey, D.J., 1997, Discouraged borrowers: A study of micro and small businesses in Trinidad and Tobago, University of Warwick working paper.

Strahan, P.E., and J. Weston, 1996, Small business lending and bank consolidation: Is there cause for concern? current issues in Economics and Finance 2, Federal Reserve Bank of New York 2, 1-6.

Strahan, P.E. and J. Weston, 1998, Small business lending and the changing structure of the banking industry, Journal of Banking and Finance 22.

Stulz, R., and H. Johnson., 1985, An analysis of secured debt, Journal of Financial Economics 14, 501-22.

Swary, I. and G.F. Udell, 1988, Information production and the secured line of credit, New York University Working Paper.

Thakor, A.V. 1998, Comment on Trester, Journal of Banking and Finance 22.

Thakor, A.V., and G.F. Udell, 1987, An economic rationale for the pricing structure of bank loan commitments, Journal of Banking and Finance 11, 271-289.

Townsend, R., 1979, Optimal contracts and competitive markets with costly state verification, Journal of Economic Theory, 21, 265-93.

Trester, J.J. 1998, Venture capital contracting under asymmetric information, Journal of Banking and Finance 22. 


$$
\mathrm{R}-13
$$

Tyebjee, T.T. and A.V. Bruno, 1984, A model of venture capitalist investment activity, Management Science 30, $1051-1066$.

U.S. Small Business Administration, 1995, The annual report on small business and competition.

Wagster, J., 1997, The Basle Accord of 1988 and the international credit crunch of 1989-1992, working paper, Wayne State University.

Walraven, N., 1997, Small business lending by banks involved in mergers, Finance and Economics Discussion Series 97-25, Board of Governors of the Federal Reserve.

Welch, I., 1997, Why is bank debt senior? A theory of asymmetry and claim priority based on influence costs, Review of Financial Studies 10, 1203-1236.

Wetzel, W.E. Jr., 1994, Venture capital, Portable MBA in entrepreneurship, ed., W.D. Bygrave. New York: John Wiley \& Sons, 172-94.

Whalen, G., 1995, Out-of-state holding company affiliation and small business lending, Office of the Comptroller of the Currency, Economic and Policy Analysis working paper 95-4.

White, L.J., 1995, An analytical framework, in S.N. Zahid, ed., Financial sector development in Asia, New York: Oxford University Press, 3-35.

Wilson, P.F., 1993, The pricing of loans in a bank-borrower relationship. Indiana University working paper.

Williamson, O., 1967, The economics of defense contracting: incentives and performance in issues in Defense Economics, ed. R. McKean. New York: Columbia University Press.

Williamson, O., 1988, Corporate finance and corporate governance, Journal of Finance 43, 567-591.

Wolken, J.D., 1998, "New” data sources for research on small business finance, Journal of Banking and Finance 22.

Wright, M., K. Robbie and C. Ennew, 1997, Serial entrepreneurs, British Journal of Management 8, 251-268.

Zardkoohi, A., and J. Kolari, 1997, The effect of structural changes in the U.S. banking industry on small business lending, working paper, Texas A\&M University. 
Table 1

U.S. Small Business Finance at a Glance:

Estimated Distributions of Equity and Debt

Percent of Total Equity Plus Debt (top numbers), and Billions of Dollars (bottom numbers)

\begin{tabular}{|c|c|c|c|c|c|c|c|c|c|c|c|}
\hline \multicolumn{5}{|c|}{ Sources of Equity } & \multicolumn{3}{|c|}{ Financial Institutions } & \multicolumn{3}{|c|}{$\begin{array}{l}\text { Sources of Debt } \\
\text { Nonfinancial Business and } \\
\text { Government }\end{array}$} & \\
\hline $\begin{array}{l}\text { Principal } \\
\text { Owner }^{h}\end{array}$ & $\begin{array}{l}\text { Angel } \\
\text { Finance }\end{array}$ & $\begin{array}{l}\text { Venture } \\
\text { Capital }\end{array}$ & $\begin{array}{l}\text { Other } \\
\text { Equity }\end{array}$ & $\begin{array}{l}\text { Total } \\
\text { Equity }\end{array}$ & $\begin{array}{l}\text { Commercial } \\
\text { Banks }\end{array}$ & $\begin{array}{l}\text { Finance } \\
\text { Companies }\end{array}$ & $\begin{array}{l}\text { Other } \\
\text { Fin. } \\
\text { Insts. }\end{array}$ & $\begin{array}{l}\text { Trade } \\
\text { Credit }^{c}\end{array}$ & $\begin{array}{l}\text { Other } \\
\text { Business }\end{array}$ & Govt. & $\begin{array}{l}\text { Principal } \\
\text { Owner }^{d}\end{array}$ \\
\hline
\end{tabular}

A: All Nonfarm, Nonfinancial, Nonreal-Estate Small Businesses ${ }^{t}$

\begin{tabular}{|c|c|c|c|c|c|c|c|c|c|c|c|}
\hline $\begin{array}{l}31.33 \% \\
\$ 524.3\end{array}$ & $\begin{array}{l}3.59 \% \\
\$ 60.0\end{array}$ & $\begin{array}{l}1.85 \% \\
\$ 31.0\end{array}$ & $\begin{array}{l}12.86 \% \\
\$ 215.2\end{array}$ & $\begin{array}{l}49.63 \% \\
\$ 830.6\end{array}$ & $\begin{array}{l}18.75 \% \\
\$ 313.8\end{array}$ & $\begin{array}{l}4.91 \% \\
\$ 82.1\end{array}$ & $\begin{array}{l}3.00 \% \\
\$ 50.1\end{array}$ & $\begin{array}{l}15.78 \% \\
\$ 264.1\end{array}$ & $\begin{array}{l}1.74 \% \\
\$ 29.2\end{array}$ & $\begin{array}{l}0.49 \% \\
\$ 8.1\end{array}$ & $\begin{array}{l}4.10 \% \\
\$ 68.5\end{array}$ \\
\hline
\end{tabular}

B: Breakout by Size of Small Business

\begin{tabular}{|c|c|c|c|c|c|c|c|c|c|c|c|c|}
\hline $\begin{array}{l}\text { "Smaller" } \\
(<20 \text { employees } \\
\&<\$ 1 \text { mill. } \\
\text { sales })\end{array}$ & $\begin{array}{l}44.53 \% \\
\$ 175.7\end{array}$ & n.a. & n.a. & n.a. & $\begin{array}{l}56.00 \% \\
\$ 220.9\end{array}$ & $\begin{array}{l}14.88 \% \\
\$ 58.7\end{array}$ & $\begin{array}{l}3.08 \% \\
\$ 12.1\end{array}$ & $\begin{array}{l}3.53 \% \\
\$ 13.9\end{array}$ & $\begin{array}{l}11.81 \% \\
\$ 46.6\end{array}$ & $\begin{array}{l}1.06 \% \\
\$ 4.2\end{array}$ & $\begin{array}{l}0.37 \% \\
\$ 1.4\end{array}$ & $\begin{array}{l}5.59 \% \\
\$ 22.1\end{array}$ \\
\hline $\begin{array}{l}\text { "Larger" } \\
\text { ( } \geq 20 \text { employees } \\
\text { or } \geq \$ 1 \text { mill.sales) }\end{array}$ & $\begin{array}{l}27.22 \% \\
\$ 348.1\end{array}$ & n.a. & n.a. & n.a. & $\begin{array}{l}47.67 \% \\
\$ 609.6\end{array}$ & $\begin{array}{l}19.94 \% \\
\$ 255.0\end{array}$ & $\begin{array}{l}5.47 \% \\
\$ 70.0\end{array}$ & $\begin{array}{l}2.83 \% \\
\$ 36.2\end{array}$ & $\begin{array}{l}17.01 \% \\
\$ 217.5\end{array}$ & $\begin{array}{l}1.95 \% \\
\$ 25.0\end{array}$ & $\begin{array}{l}0.52 \% \\
\$ 6.7\end{array}$ & $\begin{array}{l}3.63 \% \\
\$ 46.5\end{array}$ \\
\hline
\end{tabular}

C: Breakout by Age of Small Business

\begin{tabular}{|c|c|c|c|c|c|c|c|c|c|c|c|c|}
\hline $\begin{array}{l}\text { "Infant" } \\
(0-2 \text { years })\end{array}$ & $\begin{array}{l}19.61 \% \\
\$ 8.6\end{array}$ & n.a. & n.a. & n.a. & $\begin{array}{l}47.90 \% \\
\$ 21.1\end{array}$ & $\begin{array}{l}15.66 \% \\
\$ 6.9\end{array}$ & $\begin{array}{l}8.33 \% \\
\$ 3.7\end{array}$ & $\begin{array}{l}3.84 \% \\
\$ 1.7\end{array}$ & $\begin{array}{l}13.40 \% \\
\$ 5.9\end{array}$ & $\begin{array}{l}1.52 \% \\
\$ 0.7\end{array}$ & $\begin{array}{l}0.33 \% \\
\$ 0.1\end{array}$ & $\begin{array}{l}6.04 \% \\
\$ 2.7\end{array}$ \\
\hline $\begin{array}{l}\text { "Adolescent" } \\
\text { (3-4 years) }\end{array}$ & $\begin{array}{l}17.37 \% \\
\$ 25.1\end{array}$ & n.a. & n.a. & n.a. & $\begin{array}{l}39.37 \% \\
\$ 56.8\end{array}$ & $\begin{array}{l}30.84 \% \\
\$ 44.5\end{array}$ & $\begin{array}{l}2.51 \% \\
\$ 3.6\end{array}$ & $\begin{array}{l}2.36 \% \\
\$ 3.4\end{array}$ & $\begin{array}{l}13.42 \% \\
\$ 19.4\end{array}$ & $\begin{array}{l}1.06 \% \\
\$ 1.5\end{array}$ & $\begin{array}{l}0.72 \% \\
\$ 1.0\end{array}$ & $\begin{array}{l}6.19 \% \\
\$ 8.9\end{array}$ \\
\hline $\begin{array}{l}\text { "Middle-Aged" } \\
\text { (5 - } 24 \text { years) }\end{array}$ & $\begin{array}{l}31.94 \% \\
\$ 324.9\end{array}$ & n.a. & n.a. & n.a. & $\begin{array}{l}48.00 \% \\
\$ 488.2\end{array}$ & $\begin{array}{l}17.86 \% \\
\$ 181.6\end{array}$ & $\begin{array}{l}5.85 \% \\
: 59.5\end{array}$ & $\begin{array}{l}2.87 \% \\
\$ 29.2\end{array}$ & $\begin{array}{l}17.10 \% \\
\$ 174.0\end{array}$ & $\begin{array}{l}2.39 \% \\
\$ 24.3\end{array}$ & $\begin{array}{l}0.44 \% \\
\$ 4.4\end{array}$ & $\begin{array}{l}3.91 \% \\
\$ 39.7\end{array}$ \\
\hline $\begin{array}{l}\text { "Old" } \\
\text { ( } 25 \text { or more years) }\end{array}$ & $\begin{array}{l}35.42 \% \\
\$ 165.8\end{array}$ & n.a. & n.a. & n.a. & $\begin{array}{l}56.50 \% \\
\$ 264.5\end{array}$ & $\begin{array}{l}17.25 \% \\
\$ 80.8\end{array}$ & $\begin{array}{l}3.28 \% \\
\$ 15.3\end{array}$ & $\begin{array}{l}3.38 \% \\
\$ 15.8\end{array}$ & $\begin{array}{l}13.86 \% \\
\$ 64.9\end{array}$ & $\begin{array}{l}0.56 \% \\
\$ 2.6\end{array}$ & $\begin{array}{l}0.54 \% \\
\$ 2.5\end{array}$ & $\begin{array}{l}3.68 \% \\
\$ 17.2\end{array}$ \\
\hline
\end{tabular}

a. Financial Institutions include commercial banks, finance companies, thrift institutions, leasing companies, brokerage firms, mortgage companies, and insurance companies.

b For proprietorships, principal owner's share of equity is by definition 100 percent.

c. Trade credit is defined as accounts payable for year-end 1992.

d. Only partnerships and corporations have principal owner loans. By definition, proprietorships do not have loans from owners.

e. Credit card debt is estimated using the typical monthly balances of business charges to both personal and business credit cards after monthly payments were made on these accounts accurately separated using the NSSBF data.

f. Represents enterprises with fewer than 500 full-time equivalent employees, excluding real estate operators and lessors, real estate subdividers and developers, real estate investment $t$ institutions, not-for-profit institutions, government entities, and subsidiaries controlled by other corporations.

Sources: All data except for angel finance and venture capital are from the 1993 National Survey of Small Business Finance (NSSBF). These data are weighted to replicate to nation's were produced by Nicole Meleney. The NSSBF data are from year-end 1993, except that the principal owner's equity, total equity, and trade credit are from balance sheets at year-end monthly balances during 1993. The angel figure is based on survey data summarized in Freear, Sohl, and Wetzel (1994) and should be considered to be just one point in a large range ( from data in Venture Economics using methods employed in Fenn, Liang, and Prowse (1997). The angel and venture estimates are not available (n.a.) by firm size or age. 
Table 2

Estimated Distribution of Small Business Debt" from Financial Institutions ${ }^{\mathrm{b}}$

\begin{tabular}{|l|l|l|l|}
\hline $\begin{array}{l}\text { All Financial } \\
\text { Institutions }\end{array}$ & $\begin{array}{l}\text { Commercial } \\
\text { Banks }\end{array}$ & $\begin{array}{l}\text { Finance } \\
\text { Companies }\end{array}$ & $\begin{array}{l}\text { Other Financial } \\
\text { Institutions }\end{array}$ \\
\hline
\end{tabular}

\section{A: Percent of Small Businesses with Financial Institution Debt (Percent of Firms)}

\begin{tabular}{|l|r|r|r|r|}
\hline $\begin{array}{l}\text { Percent of firms with debt from at } \\
\text { least one institution of this type }\end{array}$ & $54.23 \%$ & $40.57 \%$ & $12.96 \%$ & $15.30 \%$ \\
\hline $\begin{array}{l}\text { Percent of firms with debt from more } \\
\text { than one institution of this type }\end{array}$ & $19.30 \%$ & $7.00 \%$ & $2.40 \%$ & $2.60 \%$ \\
\hline $\begin{array}{l}\text { Percent of firms with this type as its } \\
\text { "primary" financial institution" }\end{array}$ & $100.00 \%$ & $86.95 \%$ & $1.62 \%$ & $11.43 \%$ \\
\hline
\end{tabular}

\section{B: Average Length of Relationship Between Small Business Firms and Each Type of Financial Institution}

\begin{tabular}{|c|c|c|c|c|}
\hline $\begin{array}{l}\text { Average length of relationships with } \\
\text { financial institutions of this type }\end{array}$ & $\begin{array}{r}6.64 \\
\text { years }\end{array}$ & $\begin{array}{r}7.77 \\
\text { years }\end{array}$ & $\begin{array}{r}5.33 \\
\text { years }\end{array}$ & $\begin{array}{r}4.78 \\
\text { years }\end{array}$ \\
\hline $\begin{array}{l}\text { Average length of relationship with } \\
\text { "primary" institution if it is this type }\end{array}$ & $\begin{array}{r}9.01 \\
\text { years }\end{array}$ & $\begin{array}{r}9.37 \\
\text { years }\end{array}$ & $\begin{array}{l}7.21 \\
\text { years }\end{array}$ & $\begin{array}{r}6.49 \\
\text { years }\end{array}$ \\
\hline
\end{tabular}

\section{C: Percent of Each Type of Financial Institution's Small Business Debt by Category of Loan or Lease}

\begin{tabular}{|c|c|c|c|c|}
\hline Credit Lines Used & $52.03 \%$ & $56.35 \%$ & $52.13 \%$ & $24.83 \%$ \\
\hline Mortgage Loans $^{d}$ & $13.89 \%$ & $14.91 \%$ & $6.94 \%$ & $18.92 \%$ \\
\hline Equipment Loans & $10.71 \%$ & $10.21 \%$ & $14.81 \%$ & $7.12 \%$ \\
\hline Motor Vehicle Loans & $6.08 \%$ & $3.99 \%$ & $14.62 \%$ & $5.16 \%$ \\
\hline Capital Leases & $5.65 \%$ & $2.45 \%$ & $6.83 \%$ & $23.71 \%$ \\
\hline Other Loans & $11.64 \%$ & $12.09 \%$ & $4.66 \%$ & $20.25 \%$ \\
\hline Total & $100.00 \%$ & $100.00 \%$ & $100.00 \%$ & $100.00 \%$ \\
\hline
\end{tabular}

\section{D: Percent of Each Type of Financial Institution's Small Business Debt by Collateral and Guarantee Status}

\begin{tabular}{|l|r|r|r|r|}
\hline $\begin{array}{l}\text { Percent of debt from this type of } \\
\text { institution that is secured }\end{array}$ & $91.94 \%$ & $91.99 \%$ & $94.34 \%$ & $87.72 \%$ \\
\hline $\begin{array}{l}\text { Percent of debt from this type of } \\
\text { institution that is guaranteed }\end{array}$ & $51.63 \%$ & $53.82 \%$ & $51.08 \%$ & $38.87 \%$ \\
\hline
\end{tabular}

a. Debt of nonfarm, nonfinancial, nonreal-estate small businesses as described in Table 1, note $\mathrm{f}$.

b. Financial institutions include commercial banks, finance companies, thrift institutions, leasing companies brokerage firms, mortgage companies, and insurance companies.

c. A firm's "primary" institution is the one designated by the firm as its primary provider of financial services, including loan, deposit, and other services. It is not necessary to have a loan to have a "primary" institution -almost all firms use financial institutions for deposit services. A few firms that did not have any relations with financial institutions were neglected for the calculations of "primary" institution.

d. Mortgages include both commercial and residential mortgages if the funds were used for business purposes.

e. Secured debt includes the credit lines used and other loans that are reported as secured, plus all equipment loans, all mortgage loans, all motor vehicle loans, and all capital leases.

f. Guaranteed debt includes the used credit lines, mortgage loans, motor vehicle loans, equipment loans, and other loans that are reported as guaranteed. Capital leases by definition are not guaranteed. 


\section{FIGURE I}

\section{Firm Continuum and Sources of Finance}

Firm Size

Firm Age

Information Availability

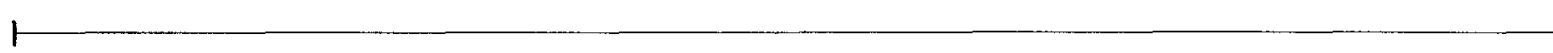

$\begin{array}{llll}\text { Very small firms, possibly } & \text { Small firms, possibly } & \text { Medium-sized firms. } & \text { Large firms of } \\ \text { with no collateral and } & \text { with high growth } & \text { Some track record. } & \text { known risk and } \\ \text { no track record. } & \begin{array}{l}\text { potential but often } \\ \text { with limited track }\end{array} & \text { Collateral available, } & \text { track record. } \\ & \text { if necessary. } & \end{array}$

record.

- Initial Insider Finance

$\downarrow$ Angel Finance $\rightarrow$ Venture Capital $\rightarrow \quad$ Public Equity
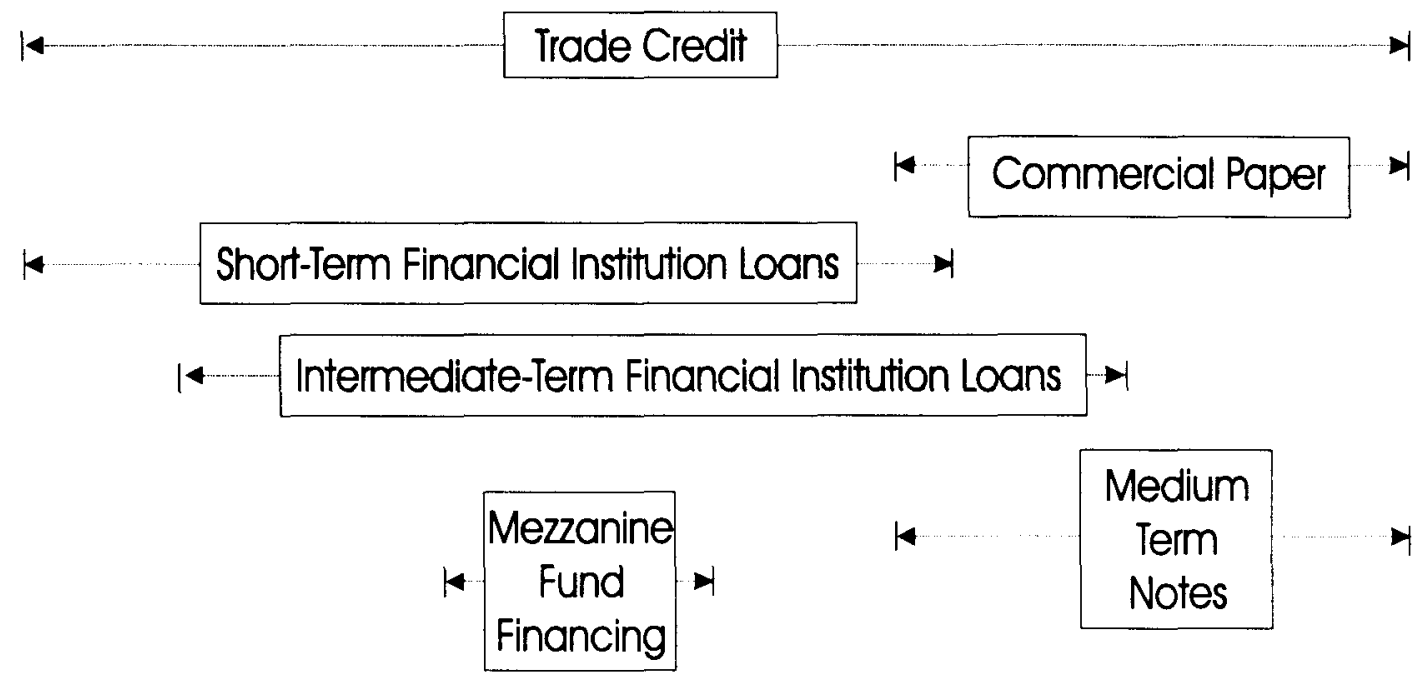

14 Private Placements

14 Public Debt 